\title{
Signs of Hero Cult in Homeric Poetry
}

\section{Citation}

Nagy, Gregory. 2012. "Signs of Hero Cult in Homeric Poetry." In Homeric Contexts: Neoanalysis and the Interpretation of Oral Poetry, eds. Franco Montanari, Antonios Rengakos, Christos C. Tsagalis, 27-71. Berlin and Boston: De Gruyter, 2012.

\section{Published Version}

doi:10.1515/9783110272017.27

\section{Permanent link}

http://nrs.harvard.edu/urn-3:HUL.InstRepos:14531726

\section{Terms of Use}

This article was downloaded from Harvard University's DASH repository, and is made available under the terms and conditions applicable to Other Posted Material, as set forth at http:// nrs.harvard.edu/urn-3:HUL.InstRepos:dash.current.terms-of-use\#LAA

\section{Share Your Story}

The Harvard community has made this article openly available.

Please share how this access benefits you. Submit a story.

Accessibility 


\section{Signs of Hero Cult in Homeric Poetry \\ Gregory Nagy}

Originally published in Homeric Contexts: Neoanalysis and the Interpretation of Oral Poetry (ed. F. Montanari, A. Rengakos, and C. Tsagalis) 27-71. Trends in Classics Supplementary Volume 12. Berlin and Boston. The page-numbers of the printed version are embedded within brackets in this electronic version: for example, $\{27 \mid 28\}$ marks where p. 27 stops and p. 28 begins.

\section{Introduction to the main argument}

This essay centers on the ancient Greek practice of worshipping heroes in the context of hero cults. ${ }^{1}$ The question to be addressed here is whether this practice was as yet current in the era when Homeric poetry took shape, and whether we may expect any signs of hero cult in this poetry. ${ }^{2}$ Concentrating on Homeric references to ritual honors received by heroes, I argue that such references are in fact signs of hero cult. Among these signs, as we will see, are references to the prospect of heroic immortalization after death, which is a primary theme of hero cult. ${ }^{3}$ The main point of my argument, as we will also see, is that these signs are integrated into the overall structure of both the Iliad and the Odyssey.

\footnotetext{
${ }^{1}$ A reliable guide to the material evidence about hero cults in the ancient Greek world is the book of Ekroth 2002, which includes a wide-ranging bibliography tracking the relevant research (there is a helpful review by Currie 2003); also, I recommend the article of Ekroth 2009, which provides a useful overview. Further references in Nagy 2001a:15n1.

${ }^{2}$ For background on this question, see Bravo 2009:13-17 (with the corresponding notes at pp. 26-28).

${ }^{3}$ On myths about the immortalization of heroes after death and on the relevance of these myths to rituals as practiced in cults of heroes, I offer an overview in the essay "The Epic Hero," Nagy 2006 (this online version of the article provides detailed notes not included in the printed version, Nagy 2005a).
} 


\section{A word about methodology}

When I speak, as I just did, of the overall structure of the Iliad and Odyssey, I have in mind a special way of looking at Homeric poetry-a special method. I approach the text of this poetry, with all its attested variations, as empirical evidence for the workings of a formulaic system, the $\{27 \mid 28\}$ study of which was pioneered by Milman Parry and Albert Lord. ${ }^{4}$ Such an approach depends on diachronic as well as synchronic perspectives ${ }^{5}$ in analyzing the operation of this formulaic system in the making of Homeric poetry. ${ }^{6}$ In using these terms synchronic and diachronic, I rely here on working definitions stemming from the lectures of the linguist Ferdinand de Saussure, which I paraphrase this way from the original French wording:
A synchronic perspective has to do with the static aspect of linguistic analysis, whereas a diachronic perspective deals with various kinds of evolution. So synchrony and diachrony refer respectively to an existing state of a language and to phases of evolution in the language. ${ }^{7}$

I note especially the equation here of diachronic and evolutionary. In this essay, I will be contrasting what is basically an evolutionary approach with alternative approaches based on the idea of prototypical written texts of Homer.

To view the Homeric Iliad and Odyssey as an overall structure shaped by a formulaic system is radically different from viewing these two epics as texts created by way of writing. From the

\footnotetext{
${ }^{4}$ The primary works are Parry 1971 (that is the publication year of his collected papers), Lord 1960 (second edition 2000).

${ }^{5}$ For background on the terms synchronic and diachronic (as formulated by Saussure [1916]), including remarks on the special relevance of these terms to Homeric studies, see Nagy 2003:1.

${ }^{6}$ Nagy 1996b:21, 25-26.

${ }^{7}$ Saussure 1916:117: "Est synchronique tout ce qui rapporte à l'aspect statique de notre science, diachronique tout ce qui a trait aux évolutions. De même synchronie et diachronie désigneront respectivement un état de langue et une phase d'évolution." For background on the original wording and on my paraphrase, including remarks on the special relevance of these terms to Homeric studies, see Nagy 2003:1.
} 
second point of view, whatever principles of organization we may find in the Iliad and Odyssey would have to depend on the writing down of these two epics at a given time and in a given place. From the first point of view, by contrast, the organization of the Iliad and Odyssey stemmed from the workings of oral poetry.

When I say oral poetry, I mean a specialized language derived from ordinary language. Just as ordinary languages are systems that operate by way of rules, so also oral poetry, as a specialized language, is a specialized $\{28 \mid 29\}$ system that operates by way of its own specialized rules. That is the essence of what I have been calling the formulaic system of oral poetry. ${ }^{8}$

It would be a gross misunderstanding, however, to think of such a formulaic system as some kind of impersonal machine. Just as ordinary language is spoken by real persons in real situations, so also the specialized language of oral poetry is composed in performances by real persons in real situations. Here I find it relevant to apply the terms langue and parole as originally developed by Ferdinand de Saussure and as later refined by Roman Jakobson: I use the term langue with reference to language as a system and the term parole with reference to language as it comes to life once it is spoken by real persons speaking in real situations. ${ }^{9}$ To restate the point, then, I am saying that the langue of oral poetry becomes parole when it is composed in performance by real persons in real situations. ${ }^{10}$

\footnotetext{
${ }^{8}$ Nagy 1990a 1§§22-44 (= pp. 29-42). See also in general Bakker 2005.

${ }^{9}$ Here is the formulation of Saussure (1916, as translated by Baskin 1966:14): "[langue] is the social side of language, outside the individual," which "exists only by virtue of a sort of contract signed by the members of the community," while parole is "the individual side of language, the individual act." This formulation, in its translated version, was adjusted by Jakobson in a posthumously published essay "Langue and Parole: Code and Message" (Jakobson 1990:80-109). For Jakobson, langue is not "outside the individual," since each individual uses langue. Conversely, when Saussure (p.13) says about parole that "the individual is always its master," Jakobson (p. 93) counterargues that parole is "not a purely individual act ... but rather an interpersonal phenomenon." Jakobson emphasizes that parole is an act of receiving as well as sending a message: "the act of receiving ... is as indispensable for parole as the act of sending" (p. 92).

${ }^{10}$ Nagy 1996b:15; 1990a 1§2n2 (= p. 17).
} 
The formulaic system of oral poetry, as a special language, has special rules that go beyond ordinary language, and these special rules can lead to ever higher levels of organization. What I just said about oral poetry on the level of langue can be restated on the level of parole: the fact is, speakers of the special language that is oral poetry can develop special mental powers of organization, and this fact can be validated in empirical studies of living oral traditions. ${ }^{11}$

So we have reason to expect oral traditions to be capable of generating highly organized structures in the process of composition in performance. Such a capacity, however, will not be recognized by those who assume that oral traditions are by nature disorganized, and this $\{29 \mid 30\}$ assumption has in fact pervaded the history of research on Homeric poetry. ${ }^{12}$ On the basis of this assumption, those who see a unity in the organization of the Homeric Iliad and Odyssey will explain such unity in terms of literacy. By contrast, I explain such unity in terms of oral poetics. ${ }^{13}$ Given that the term unitarian has been used in the past to describe those who see Homeric unity of organization in terms of literacy, I hereby propose to use the term neounitarian to describe my stance in seeing this same Homeric unity in terms of oral poetry, and I hope to justify my use of this term as my argumentation proceeds. ${ }^{14}$ From the viewpoint of a neounitarian approach, I argue, references to hero cult in Homeric poetry are interconnected signs embedded in the formulaic system of Homeric poetry.

\footnotetext{
${ }^{11}$ Nagy 1996b:19, 26-27, 30, 40, 137.

${ }^{12}$ Nagy 1996b:26.

${ }^{13}$ See Nagy 2006\$40. And, as I point out there, with reference to ethnographic studies of living oral traditions, concepts of unity can actually be recognized not only by the practitioners of these traditions in contexts of live performance but also by those who attend the performance or participate in it. See also especially Nagy 2003:15n74, with reference to the ethnographic concept of "notional totality."

${ }^{14}$ I recognize that the term can be used in different ways, as we can see from the analysis of Cerri 2010:85; also Theiler 1962.
} 


\section{Different ways of looking at references to hero cult in Homeric poetry}

The argument that I am making here about interconnected signs of hero cult in Homeric poetry goes back ultimately to a book I first published in 1979, The Best of the Achaeans. ${ }^{15}$ This argument has been challenged in a book published in 2005 by Bruno Currie on the cult of heroes as reflected in the poetry of Pindar, especially in the genre that we know as the victory ode or epinician. ${ }^{16}$ In that book, for which I express from the start my deepest admiration, we find a different way of looking at references to hero cult in Homeric poetry-and, more basically, a different way of looking at Homeric poetry. Currie's argumentation, as we will see, is not only different from mine when it comes to Homer: it $\{30 \mid 31\}$ seems to be meant as an outright replacement of what I have argued about hero cults and Homer. In what follows, my aim is to respond not only by defending my arguments but also by showing that Currie's differences with me would be reconciled if I could persuade him to adjust the lens through which he views Homeric poetry. My defense is framed in a form of debate where the question is not whether anyone has won or lost an argument. The question to be faced, rather, is whether the debate can be framed within a broader framework that reconciles what may at first seem to be irreconcilable points of view about Homeric poetry. ${ }^{17}$

To start my defense, I go back to something I said in the second edition of The Best of the Achaeans, published in 1999, twenty years after the original publication. In the 1999 Preface

\footnotetext{
${ }^{15}$ Nagy 1979, abbreviated hereafter as BA; second edition 1999, abbreviated hereafter as $B A^{2}$.

${ }^{16}$ Currie 2005.

${ }^{17}$ My hope for reconciliation is keen. That is not only because I happen to think that Currie's 2005 book is the best synthesis I have ever read about Pindar but also because this book complements my own work on that author. I have in mind especially the book Pindar's Homer (Nagy 1990a), in which I analyze hero cults in the context of a large-scale comparative study of the relationship between Homeric and Pindaric poetry. I find most relevant to my work the insights of Currie concerning not only into the practices of hero cult, which he views in terms of both ritual and myth, but also the genre of the victory ode itself, which he analyzes most effectively in its genuine historical contexts.
} 
that supplants the original 1979 Foreword written by James Redfield, I make an overall statement about Homeric references to hero cults. I go out of my way here to situate this statement in my Preface to the 1999 edition of The Best of the Achaeans because most works on Homer published within the last ten years cite only the 1979 edition of my book. In the case of Currie's work, he too cites only the 1979 edition.

As we are about to see, my 1999 statement can be used as a point of departure for defending my views on Homeric references to hero cults. In this statement, which centers on the evidence of Homeric and other poetic passages quoted in The Best of the Achaeans, I argue for the formative influence of the cult of heroes on the epics of heroes as represented by the Homeric Iliad and Odyssey: ${ }^{18}$

The object of all the readings [of the Homeric and other poetic passages I quote in the book] is to understand simultaneously the form as well as the content of a wide variety of traditional media conveying various basic concepts of the ancient Greek hero. The most basic of all these concepts is a single all-pervasive historical fact of the archaic period and beyond: the cult of heroes. Heroes were not only the subjects of narrative and dramatic $\{31 \mid 32\}$ media but also the objects of worship. This book integrates heroic song, poetry, and prose with the ancestral practices of a wide variety of hero cults. ${ }^{19}$ More generally, it explores the heroic tradition within the cultural context of Panhellenism, to be defined as an early form of Hellenism that eventually became the nucleus of Classicism..$^{20}$

\footnotetext{
${ }^{18} B A^{2}$ Preface $\$ 3$ (= p. vii).

${ }^{19}$ Reference here to $B A$ Introduction $\S \S 16-19$ (= pp. 9-10).

${ }^{20}$ Reference here to $B A$ Introduction $\$ \S 13-15$ (= pp. 6-9).
} 
As I say explicitly in this 1999 statement, the emphasis in my 1979 book The Best of the Achaeans is on the all-pervasive presence of the cult hero in all forms of archaic Greek literature, including the epic form of Homeric poetry. And here is the way I formulate this presence in the 1979 introduction to the book: $:^{21}$

I have set as my main goal the answer to this vital question about the Achilles of our Iliad: does this Panhellenic figure possess the religious dimension of a cult hero even within Epos? There are other questions that are related: how is myth stylized in epic, and how does poetry in general express the connections between myth and ritual?

The point I am making in this formulation, that Achilles as well as the other heroes who are represented in the Homeric Iliad and Odyssey possess "the religious dimension of a cult hero," differs from the point made in the 2005 book of Currie, who begins his chapter on "Hero Cult" by saying: "There is near total silence on hero cult in Homer." ${ }^{\text {"2 }}$ Although Currie recognizes, as I do, that the religious dimension of hero cult as it exists in the historical period of Pindar in the fifth century $B C E$ had already taken shape in the prehistoric period of Homeric poetry, the "final form" of which he dates to the last quarter of the eighth century $\mathrm{BCE},{ }^{23}$ he goes on to argue for a Homeric "suppression" of such a religious dimension, especially with regard to the theme of the cult hero's immortalization after death. Besides the word "suppress," which Currie uses frequently in his relevant discussion, ${ }^{24}$ he uses also the wording "pointedly

\footnotetext{
${ }^{21}$ BA Introduction $\$ 19$ (= p. 10).

${ }^{22}$ Currie 2005:46.

${ }^{23}$ Currie 2005:48.

${ }^{24}$ Currie 2005:50-57.
} 
overlook" as a synonym. ${ }^{25}$ Why such a "suppression"? Currie's book considers three possible explanations.

The first explanation, as originally formulated by Theodora Hadzisteliou-Price, is that the medium of epic would have seemed anachronistic $\{32 \mid 33\}$ in treating personages of the past as if they were already cult heroes of the present. ${ }^{26}$ Currie rejects this explanation, noting that media like tragedy are perfectly capable of treating personages of the past as if they were already cult heroes ${ }^{27}$ By contrast, according to Currie, the medium of Homeric poetry "suppresses" such a treatment. As I intend to argue, however, Homeric poetry can in fact refer to its characters as if they were already cult heroes.

A second explanation for "the suppression of hero cult from Homeric epic" is a formulation that Currie attributes to me. To quote his own wording, I argue that "the Panhellenic orientation of Homeric epic meant that it had to shed any allusions to local hero cult." ${ }^{28}$ To back up what he claims I argue, he quotes the following formulation of mine in The Best of the Achaeans: ${ }^{29}$

The hero of cult must be local because it is a fundamental principle in Greek religion that his power is local. On the other hand, the Iliad and the Odyssey are Panhellenic. What results is that the central heroes of this epic tradition cannot have an overtly religious dimension in the narrative.

As my wording here indicates, however, I am not saying that epic had "shed any allusions to local hero cult." I am saying only that Homeric poetry avoids overt references to hero cult. To

\footnotetext{
${ }^{25}$ Currie 2005:55. He also quotes here Lloyd-Jones 1983:81, who speaks of "a kind of censorship."

${ }^{26}$ Hadzisteliou-Price 1973.

${ }^{27}$ Currie 2005:55.

${ }^{28}$ Currie 2005:56.

${ }^{29}$ BA $6 \$ 29(=$ p. 116).
} 
say it another way, references to hero cult are implicit, not explicit, in Homeric poetry. ${ }^{30}$ And, as I argue, Homeric poetry not only "alludes" to hero cult but also actually integrates the mentality of hero cult into the overall narratives of both the Iliad and the Odyssey.

As for the Panhellenic orientation of the Homeric poems, I submit that Currie has not yet fully come to terms with what I mean by Panhellenism, which is for me an absolutizing tendency rather than any absolute reality in Homeric poetry. In my studies on Homer poetry, the term Panhellenic is relative, not absolute. ${ }^{31}$ That is why I can describe the Homeric Iliad and Odyssey as "more Panhellenic" than, say, the epic Cycle. ${ }^{32}$ In other words, the Iliad and Odyssey are less localized $\{33 \mid 34\}$ in outlook than the epics of the Cycle. A case in point is the theme of heroic immortalization after death, which is a primary characteristic of localized myths that are linked with localized hero cults. ${ }^{33}$ This theme is made explicit in the Aithiopis, an epic belonging to the Cycle and attributed to Arctinus of Miletus: in this epic, Achilles is explicitly immortalized after death (Aithiopis Proclus summary p. 106.11-15); in the Homeric Iliad and Odyssey, by contrast, the theme of heroic immortalization is nowhere made explicit for Achilles. ${ }^{34}$ In this particular instance, then, with specific reference to the theme of immortalization as a characteristic of localized hero cults, I can say that the Homeric Iliad and Odyssey are "more Panhellenic" and thus "less localized" in comparison to the epic Cycle.

My formulation, as I just repeated it here, has been summarized by Currie: "The argument that the Iliad and Odyssey are 'more Panhellenic' than the poems of the Epic Cycle provides for Nagy an explanation of why the former admit fewer allusions to immortalization and hero

\footnotetext{
${ }^{30}$ This point is picked up by Bravo 2009:16-17.

${ }^{31}$ Nagy 1996b:40-41; 2009a:274-275.

${ }^{32}$ Nagy 1990a $2 \$ 36$ (= pp. 70-71).

${ }^{33}$ Nagy $2006 \S \S 98-99,107,113$.

${ }^{34}$ Nagy 2006 \$57. There is, however, an implicit reference to the future immortalization of Achilles in Iliad XIX 418, as analyzed in BA 10\$50n2 (= pp. 209-210).
} 
cult." ${ }^{35}$ In this context, while focusing on the concept of Panhellenism, Currie sets up my explanatory model as a foil for his own explanation.

Before I turn to Currie's explanation, however, I must record my disagreement with his own use of the term "Panhellenic" in a secondary argument that he adds in this same context. It has to do with references in the Homeric Iliad to the mortality of the hero Herakles (XVI 431461, 666-683, XVIII 117). These references avoid any direct mentioning of immortalization, which as we have seen is a primary theme of hero cults. And the fact is, this theme of immortalization after death pervades the myths about Herakles outside of Homeric poetry. ${ }^{36}$ In terms of my explanatory model, then, the avoidance of references to the immortalization of Herakles in the Iliad is due to the Panhellenism of Homeric poetry, which promotes the exclusion of explicit references to hero cults. And here is where Currie offers his secondary argument against my explanation of such a pattern of exclusion in terms of Homeric Panhellenism: $\{34 \mid 35\}$ "the cult of Herakles, although a Panhellenic and not a local one, is no more immune to exclusion from the Iliad than the cults of other heroes. ${ }^{37}$ I disagree with this description of the cults of a hero like Herakles as "Panhellenic."38

The fact that there were many hero cults of Herakles all over the Hellenic world does not mean that any single one of these cults was Panhellenic. ${ }^{39} \mathrm{I}$ hold that the cults of Herakles and

\footnotetext{
${ }^{35}$ Currie 2005:56.

${ }^{36}$ I analyze the myths about the immortalization of Herakles in Nagy $2006 \S \S 74-75,105-108$. In the ancient Greek visual arts, the death and subsequent immortalization of Herakles can be represented simultaneously: see Pache 2009:105-106.

${ }^{37}$ Currie 2005:56.

${ }^{38}$ Currie 2005:56.

${ }^{39}$ For an overview of the wide variety of the local hero cults of Herakles, see Larson 2009:35-39. A most telling indication of the local character of these various cults is the enormous number of myths concerning different sons that Herakles fathered in different locales: Larson pp. 37-38 gives a survey.
} 
all other hero cults, as cults, were local rather than Panhellenic. ${ }^{40}$ And, in terms of my argumentation, the Homeric Iliad avoids explicit references to the hero cults of Herakles precisely because these cults were local, just as all other hero cults were local.

Currie's inventory of three possible reasons for "the suppression of hero cult from Homeric epic" culminates in a third explanation, which is his own. In his opinion, the "suppression" results from what he describes as "the literary aims of Homeric epic." ${ }^{41}$ This third explanation is presented as a replacement for my own overall explanation, which he describes this way: “Nagy's understanding of the 'Panhellenism' of the Homeric poems is bound up with his proposal of an 'evolutionary model' for the genesis of the Homeric poems." ${ }^{42}$ Currie goes on to describe as follows my evolutionary model for the making of Homeric poetry: "The theory ... makes impersonal, cultural, forces responsible for the suppression of hero cult in the Homeric poems, rather than any literary considerations." ${ }^{43}$

I think that this description sets up a false dichotomy between "literary considerations" and my evolutionary model, which I have already described as essentially a diachronic model. Currie derives his wording here from earlier wording used by Douglas L. Cairns in introducing a $\{35 \mid 36\} 2001$ collection of Oxford Readings in Homer's $<<$ Iliad $>{ }^{44}$ Using my evolutionary model as a foil for his own understanding of Homeric poetry, Cairns reads into this model the idea that the "ethos" of the Iliad is "attributable to impersonal forces of historical development." 45

\footnotetext{
${ }^{40}$ On the local or epichoric character of hero cults, I offer a survey in Nagy $2006 \S \S 80-104$.

${ }^{41}$ Currie 2005:56.

${ }^{42}$ Currie 2005:56 and n59, where he cites my explanation of the "evolutionary model" in Nagy 1996b:38-63. See also Currie 2006:8n45.

${ }^{43}$ Currie 2005:56.

${ }^{44}$ In claiming a dichotomy between "literary considerations" and my evolutionary model, Currie 2005:56n59 cites with approval what Cairns says in his introduction to Oxford Readings (2001:3n12).

${ }^{45}$ Cairns 2001:35; at p. 35n115, he refers to my evolutionary model as articulated in Nagy 1996b:92.
} 
Here, then, is the crux of my disagreement with Currie. He relies on the formulation of Cairns in two ways: (1) he says that I explain "the suppression of hero cult from Homeric epic" in terms of "impersonal, cultural, forces" and (2) he proposes an alternative explanation that is formulated in terms of "literary considerations." I disagree with the wording he uses to describe my explanation, and, more basically, I disagree with Cairns when he claims that I speak of "impersonal forces of historical development," to be contrasted with "the role of a single poet's design and overall conception of his work." ${ }^{46}$ The wording of Cairns exemplifies what may perhaps be described as an "old unitarian" approach. ${ }^{47}$

As I said earlier, it would be a misunderstanding to think of the formulaic system of Homeric poetry as some kind of impersonal machine. ${ }^{48}$ And, I now add, it would also be a misunderstanding to think of my evolutionary model in terms of "impersonal forces of historical development." To make this added argument, I return to the terminology developed by Saussure, who juxtaposes langue in referring to language as a system and parole in referring to language as it comes to life once it is spoken by real persons speaking in real situations. ${ }^{49}$ Applying this terminology not only to oral poetry in general but also to Homeric poetry in particular, I argue that the langue of the oral traditions underlying the Homeric Iliad and Odyssey becomes parole in the process of being performed and reperformed by real persons in real situations. ${ }^{50}$ And I return here also to the relevant formulation of Jakobson, who $\{36 \mid 37\}$ notes that parole is "not a purely individual act ... but rather an interpersonal phenomenon."

\footnotetext{
${ }^{46}$ Cairns 2001:35.

${ }^{47}$ Though Cairns speaks of "a single poet's design" and of an "overall conception," it may be inaccurate to label him as a "unitarian," as we will see in the last footnote of this essay.

${ }^{48}$ Further comments on this notion in BA Introduction $\$ 3$ (= p. 2).

${ }^{49}$ Saussure 1966 [1916] 14.

${ }^{50}$ Nagy 1996b:15; 1990a 1§2n2 (= p. 17).

${ }^{51}$ Jakobson 1990:93: this formulation has already been noted at an earlier stage of my essay.
} 
Applying this formulation to Homeric poetry, I will argue that the parole of the Homeric Iliad and Odyssey, as it comes to life in performance and reperformance, is not at all "impersonal" or even "personal" but "interpersonal."

Another formulation by Jakobson is relevant here: "the act of receiving ... is as indispensable for parole as the act of sending. ${ }^{.52}$ Just as any parole is an act of receiving as well as sending a message, so also the parole of the Homeric Iliad and Odyssey depended on the ongoing reception of these epics by the audiences that heard them being performed. Jakobson's use of the concept of receiving is pertinent to the history and prehistory of Homeric reception, which is the basis of my neounitarian formulation of an evolutionary or diachronic model for the making of Homeric poetry. ${ }^{53}$

In terms of this neounitarian formulation, the language of Homeric poetry was a dynamic interaction, through time, of langue and parole. The langue of Homeric poetry, in the course of its evolution during its phase as oral poetry, was not static but ever-changing, ever-evolving, and the linguistic changes that took place in this Homeric langue were conditioned by the historical circumstances of perennial recomposition in performance, which was the essence of Homeric parole. And this parole depended, as I argue, on the ongoing reception of Homeric poetry by the persons attending the performances of this poetry. ${ }^{54}$

From the standpoint of such a neounitarian view of Homeric poetry, what Currie describes as the "suppression" of Homeric references to hero cult is in fact a "literary" phenomenon, but my view of this term "literary" is broader, since it allows for the operation of verbal art in oral traditions, not only in written media. Further, my view of Homeric "suppression" is likewise

\footnotetext{
${ }^{52}$ Jakobson 1990:92: again, this formulation has already been noted at an earlier stage of my essay.

${ }^{53}$ With reference to Hesiodic as well as Homeric reception, I apply this formulation: "In oral traditions, there is an organic link between reception and performance, since no performance can succeed without a successful reception by the public that sees and hears the performer or performers" (Nagy 2009a:283).

${ }^{54}$ As the essay proceeds, I will highlight two historical settings for the reception of Homeric poetry.
} 
broader, since I see the general Homeric avoidance of direct references to hero cult as a pattern embedded in $\{37 \mid 38\}$ the formulaic system of Homeric poetry. Within the workings of a formulaic system, such an embedded pattern would not have happened overnight, as it were. To put it another way, such a pattern would not have resulted from any single individual poet's special way of thinking about heroes. Rather, as I argue, such a pattern resulted from an evolution in ways of thinking about heroes within the evolving formulaic system of Homeric poetry. And the evolution of this formulaic system can be viewed in terms of an ongoing and ever-evolving interaction between langue and parole.

So I resist the idea of a personal "suppression" of Homeric references to hero cult. Instead, I will argue that Homeric poetry shows a progressive loosening of ties to localized concerns about the cults of local heroes. Such a loosening of ties, as I will also argue, resulted from what I describe as the Panhellenism of the Homeric Iliad and Odyssey. And the "ethos" of this Panhellenism is not at all "impersonal." I say rather that it is "interpersonal," applying again the terminology of Jakobson concerning parole. Homeric Panhellenism can be envisaged as an evolving interaction between the langue of Homeric poetry and the parole that comes to life in the reception of this poetry.

This term interpersonal is relevant to the interaction between performer and audience in a wide variety of oral traditions around the world: in many of these traditions, what we consider to be an audience is simply a grouping of persons who not only hear and see the performer but are also considered to be part of the performance. ${ }^{55}$ Such a blurring of distinctions between audience and group is pertinent to the scenes of person-to-person or person-to-group interaction in Homeric narrative that mirror the conventions of performer-audience

\footnotetext{
${ }^{55}$ Nagy 1996a:3, 83-85, 217.
} 
interaction in the "real world" that frames the performance of the narrative ${ }^{56}$ That "real world," I argue, is reflected in the Panhellenic reception of Homeric poetry. $\{38 \mid 39\}$

\section{Historical contexts of Homeric Panhellenism and their relevance to the unity of Homeric composition}

I highlight here two historical contexts for the Panhellenic reception of Homeric poetry. I will start with the second and more recent of these contexts and then proceed to the first and more ancient one.

The more recent of the two contexts was the festival of the Panathenaia as celebrated in the late sixth century BCE in Athens. An important feature of the Panathenaia was a regulation concerning the performance of the Homeric Iliad and Odyssey by competing performers known as rhapsōidoi 'rhapsodes'. This Panathenaic Regulation, as I call it, required that these rhapsodes collaborate as well as compete with each other in the process of performing, by relay, successive parts of the Homeric Iliad and Odyssey ("Plato" Hipparkhos 228b-c). ${ }^{57}$ I argue that this regulation contributed to the unity of these two epics as they evolved over time. ${ }^{58}$

Such an evolution can best be understood in the light of the first and more ancient of the two historical contexts that I am highlighting. I argue that the Homeric performance units stemming from the Panathenaic Regulation stemmed ultimately from earlier Homeric performance units that evolved at the festival of the Panionia as celebrated in the late eighth and early seventh centuries BCE at the Panionion of the Ionian Dodecapolis in Asia Minor. ${ }^{59} \mathrm{I}$ follow here the analysis of Douglas Frame, who shows that the Panionian versions of the Iliad and the Odyssey were divided into six rhapsodic performance units each, adding up to twelve

\footnotetext{
${ }^{56}$ Nagy 1996b:54-56, following Martin 1989.

${ }^{57}$ Nagy 2008|2009 2§§297, 304, 325; 3§§4, 6, 33.

${ }^{58}$ Nagy 2002:42-47; also 1996a:69-73, 77; 1996b:75,81-84, 101-102.

${ }^{59}$ Nagy 2009|2010, especially I§§38, 54, 167, 170, 188, 231; II§328; E§§8, 22, 32.
} 
rhapsodic performance units representing each one of the twelve cities of the Ionian Dodecapolis; each one of these twelve rhapsodic performance units corresponds to four rhapsōidiai 'rhapsodies' or 'books' of the Homeric Iliad and Odyssey as we know them ('books' 1$4,5-8,9-12,13-16,17-20,21-24) .^{60}$

These two historical contexts of Homeric Panhellenization correspond to two different time frames within what I describe as five successive periods in my evolutionary or diachronic model for the making of $\{39 \mid 40\}$ Homeric poetry. ${ }^{61}$ The earlier of the two contexts corresponds to what I classify as Period 2, which extends from the middle of the eighth century BCE to the middle of the sixth, while the later one of the two corresponds to the last few decades of Period 2 and the first few decades of a larger time-frame that I classify as Period 3, which extends from the middle of the sixth century BCE all the way to the later part of the fourth. ${ }^{62}$

To start, I focus on the two or so centuries of evolution that took place during Period 2, from the middle of the eighth century BCE to the middle of the sixth. I view this period as a decisive time frame for the crystallization, as I call it, of Homeric poetry and, I must now add, also of Hesiodic poetry. I have offered this formulation concerning the crystallization of the Homeric Iliad and Odyssey and of the Hesiodic Theogony and Works and Days: ${ }^{63}$

These poems ... represent the culmination of compositional trends that were reaching their ultimate form, from the eighth century onward, in the context of competitive performances at Panhellenic festivals and other such events. By way of countless such performances for over two centuries, each recomposition

\footnotetext{
${ }^{60}$ Frame 2009 ch. 11.

${ }^{61}$ The five successive periods are summarized in Nagy 2008|2009 P\$11, recapping the more detailed presentations in Nagy 1996a:109-114 and 1996b:41-43.

${ }^{62}$ Nagy 1996a:110 and 1996b:42.

${ }^{63}$ Nagy 1990b:41-42.
} 
at each successive performance could become less and less variable. Such gradual crystallization into what became set poems would have been a direct response to the exigencies of a Panhellenic audience. ${ }^{64}$

In this earlier formulation, I did not specify which of the Panhellenic festivals I had in mind as the historical contexts for the crystallization of Homeric and Hesiodic poetry. In the present essay, I now specify the festivals of the Panionia and the Panathenaia as, respectively, the initial and the ultimate historical $\{40 \mid 41\}$ contexts of crystallization for the Homeric Iliad and Odyssey. ${ }^{65}$ As for the Hesiodic Theogony and Works and Days, by contrast, I specify only the Panathenaia as the ultimate historical context of crystallization for these two compositions. ${ }^{66}$ My reason for reconstructing a shorter time span of crystallization for Hesiodic poetry is this: during the earlier time corresponding to Period 2 in the evolution of Homeric poetry, while the Iliad and Odyssey were already taking shape in the historical context of the festival of the Panionia, there is no trace of any corresponding evolution of Hesiodic poetry at that particular festival. Only in the later historical context of the festival of the Panathenaia do we find traces of a parallel evolution of Homeric and Hesiodic poetry ${ }^{67}$ This is not to rule out the possibility that Hesiodic poetry underwent an earlier phase of crystallization in the context of other festivals corresponding roughly to Period 2 in the evolution of Homeric poetry: it is only to rule out the context of the Panionia, the time-frame for which extends as far back as the eighth century BCE. And my point is that only the Homeric Iliad and Odyssey can be dated that far back in time as I reconstruct the historical contexts for performances of such epics.

\footnotetext{
${ }^{64}$ Reference here to BA Introduction $\S \S 9-12$ (= pp. 5-9). More on crystallization in Nagy 1990a 2§§4-6 (= pp. 5354), 23 (= pp. 60-61), 14§2n4 (= p. 415).

${ }^{65}$ I refer again to the argumentation in Nagy 2009|2010, especially I§§38, 54, 167, 170, 188, 231; II§328; E§§8, 22, 32 (following Frame 2009 ch. 11).

${ }^{66}$ I refer to the argumentation in Nagy 2009a:294-295 for a Panathenaic phase of Hesiodic reception.

${ }^{67}$ Again, Nagy 2009a:294-295.
} 
In terms of my overall reconstruction, then, the crystallization of Hesiodic poetry lasted for a relatively shorter time than the crystallization of Homeric poetry, and it started later. This reconstruction meshes with the relative chronology of Homeric and Hesiodic poetry as calculated by Richard Janko. Using as his criteria a set of mutually independent linguistic archaisms and innovations, Janko shows that Homeric poetry preserves a relatively higher percentage of archaisms and a lower percentage of innovations than does Hesiodic poetry; ${ }^{68}$ more specifically, Homeric poetry tends to be relatively less Ionic than Hesiodic poetry in its formulaic diction, since it preserves relatively more pre-Ionic dialectal forms. ${ }^{69}$

Janko's statistics for differences in linguistic archaisms and innovations between the Homeric Iliad and Odyssey and between the Hesiodic Theogony and Works and Days are to my mind negligible in comparison with his important statistics for differences between Homeric and Hesiodic poetry, which are far more pronounced. As a case in point, I cite the final calculations presented by Janko: Iliad 750-725 BCE, Odyssey 743-713 BCE, Theogony 700-665 BCE, Works and Days 690-650 \{41|42\} BCE..$^{70}$ In his more recent work, Janko has situated the dating of Homeric poetry even farther back in time: 775- 750 BCE for the Iliad and "slightly later" for the Odyssey. ${ }^{71}$

For Janko, the fact that Homeric poetry is more archaic and less innovative than Hesiodic poetry in its formulaic diction means that the Homeric compositions were written down at an earlier time than the Hesiodic compositions. ${ }^{72}$ For me, this same fact means, rather, that Homeric poetry underwent the process that I call crystallization for a longer time and starting

\footnotetext{
${ }^{68}$ For an overview: Janko 1982:200.

${ }^{69}$ Janko 1982:85, 197; Nagy 1990b:61, 63.

${ }^{70}$ Janko 1982:231.

${ }^{71}$ Janko 1998:1. A critique of Janko's methods in calculating relative chronologies has been offered by Jones 2010.

${ }^{72}$ Janko 1982:192, 220-221; 1998:1, 11-12.
} 
at an earlier time than did Hesiodic poetry ${ }^{73}$ In terms of my evolutionary or diachronic model, the relatively greater archaism of Homeric poetry does not mean that it was written down earlier than, say, Hesiodic poetry was written down. The point is not that the Homeric Iliad and Odyssey were textualized earlier: rather, more simply, these two epics were crystallized earlier. To reverse the relative comparison, I can restate by saying that Hesiodic poetry was still relatively more fluid in the eighth and seventh centuries BCE, during a time when Homeric poetry was already becoming relatively less fluid and more rigid.

Up to now, I have expressed the idea of relatively more rigidity by utilizing the metaphor of crystallization. From here on, however, I utilize also a slightly different metaphor: the gradual slowing down of fluidity in the ongoing process of Homeric recomposition in performance can be seen as a bottleneck for the flow of that ongoing process. ${ }^{74}$ In terms of this new metaphor that I am now using, I can say that Homeric poetry flowed through a longer bottleneck than did Hesiodic poetry. Or, to put it in terms of the two separate Panhellenic festivals that became the historical contexts for the shaping of Homeric poetry, I can restate by saying that Homeric poetry flowed through a Panionian bottleneck in the eighth and seventh centuries BCE and through a Panathenaic bottleneck in the sixth century. ${ }^{75}$ The flow in the course of the second bottleneck slowed down so much that it gradually froze over, facilitating $\{42 \mid 43\}$ the textualization of Homeric poetry in this relatively late period. ${ }^{76}$ Likewise, Hesiodic poetry flowed through a Panathenaic Bottleneck in the sixth century BCE, and it too gradually froze over. ${ }^{77}$ But Homeric poetry had a head start, as it were, since its flow started slowing down at

\footnotetext{
${ }^{73}$ Nagy 1996b:111.

${ }^{74}$ Nagy 2003:69-70; 2004:30, 185.

${ }^{75}$ Nagy 2009|2010 E\$8.

${ }^{76}$ I develop further the metaphor of a gradual freezing over of oral traditions in Nagy 2008|2009 1§7, where I have more to say about the aesthetics of the concept of crystallization.

${ }^{77}$ Again, Nagy 2009|2010 E§8.
} 
an earlier date and so it started freezing at an earlier date. By contrast, the relatively later freezing of Hesiodic poetry yielded relatively fewer linguistic archaisms than what we find in Homeric poetry.

Keeping my focus on the two historical contexts of the Panionian and the Panathenaic festivals, I turn to yet another aspect of the Panhellenization of Homeric poetry. That other aspect can be formulated this way: the Panhellenic diffusion of this poetry was both centrifugal and centripetal. My original formulation, which was made with reference to the Panathenaia, without any mention of the Panionia, highlighted a comparable phenomenon that is clearly observable in the living oral epic traditions of latter-day India: ${ }^{78}$

As the comparative evidence of oral epic traditions in contemporary India shows, the institution of Homeric performances at the Panathenaia can be visualized as a process of diffusion. [... But this] diffusion is not restricted to the pattern of an ever-widening radius of proliferation, with no clearly defined center of diffusion. As the Indic comparative evidence shows, there is also a more specialized pattern that can be predicated on a functional center point, bringing into play both centripetal and centrifugal forces. Such a center point ... can take the form of a centralized context for both the coming together of diverse audiences and the spreading outward of more unified traditions.

As I went on to argue, the centripetal coming together of diverse audiences representing multiform epic traditions at a festival like the Panathenaia is correlated with the centrifugal diffusion of an ever more uniform epic tradition of Homeric poetry as it radiates outward from

\footnotetext{
${ }^{78}$ Nagy 1996b:52.
} 
its Panathenaic center ${ }^{79}$ The wider this Homeric tradition spreads, the closer it gets to achieving its ultimate uniformity. Here I come back to the metaphor of crystallization, which corresponds to the idea of $\{43 \mid 44\}$ such an ultimate uniformity in Homeric poetry. ${ }^{80} \mathrm{I}$ am saying that the crystallization of Homeric poetry is Panhellenic-or, to express it in relative terms, that Homeric poetry becomes the most Panhellenic of all forms of epic. ${ }^{81}$

My evolutionary or diachronic model of Homeric crystallization as an ongoing process extending from the eighth through the sixth century $\mathrm{BCE}$ is incompatible with an alternative model built by Janko, which centers on his theory that the Homeric Iliad and Odyssey were textualized already in the eighth century BCE by way of being dictated sometime in that early period ${ }^{82}$ In terms of Janko's dictation theory, the Homeric Iliad and Odyssey were already integral texts from the eighth century BCE onward. While arguing against my model of Homeric crystallization, which I view as a process continuing from the eighth through the sixth century BCE, Janko describes it this way: "the progressively wider and wider diffusion of the Homeric poems resulted in their becoming more and more fixed." ${ }^{83}$ Janko objects to this model by claiming that such diffusion would have resulted in more and more fluidity instead of more and more rigidity. ${ }^{84}$ In making this claim, however, he considers only half of my

\footnotetext{
${ }^{79}$ Nagy 1996b:43; 2003:70 and n76, with further argumentation.

${ }^{80}$ Nagy 1996b:109. In this context, I compare a similar though hardly identical use of the metaphor of crystallization. It comes from Radloff (1990 [1885] 78), describing the formation of Kirghiz epic traditions: "Like new crystals that develop in a saturated sodium solution during evaporation and group together around a large crystal center in the fluid, or like fine iron filings that cluster around the magnetic pole, all single legends and tales, all historical memories, stories, and songs are strongly attracted to the epic centers and become, by being broken into pieces, parts of a comprehensive picture."

${ }^{81}$ For a comparison of the Panhellenism of the Homeric Iliad and Odyssey with the Panindianism of the primary Sanskrit epics, the Mahābhārata and the Rāmāyaṇa, see Nagy 1996b:45-47.

${ }^{82}$ Janko 1982:192, 220-221; 1998:1, 11-12.

${ }^{83}$ Janko 1998:12n63.

${ }^{84}$ Janko 1998:11-12.
} 
argument, since he views the diffusion of Homeric poetry only in terms of centrifugal forces. He does not take into account the other half of my argument: as I have already pointed out, I argue also for centripetal forces that shape the consolidation of Homeric poetry in the historical contexts of festivals.

Cairns says he agrees with Janko in opposing my argument "that the oral tradition of the Homeric poems crystallized in a relatively stable 'formative' period from the mid-8th to the mid-6th cent[ury]," ${ }^{\prime 85}$ and $\{44 \mid 45\}$ he also agrees with Janko's dating of the textualization of Homeric poetry in the mid-eighth century BCE. ${ }^{86} \mathrm{I}$ must note, however, that his paraphrase of my argument blurs the fact that I view Homeric crystallization as a gradual process, not as some kind of a deep freeze that supposedly lasted for two centuries. Cairns goes on to assume such a deep freeze of Homeric poetry, claiming that I argue for the oral transmission of an already frozen composition. Holding on to that assumption, he asserts that such an argument is untenable even in terms of oral poetics: "but oral transmission makes modification and development inevitable, and consistent archaism on the scale required is surely impossible." ${ }^{87}$ This way, Cairns rules out the possibility of oral transmission for Homeric poetry from the mid-eighth to the mid-sixth century BCE on the grounds that the embedded linguistic archaisms of Homeric poetry would have been gradually eliminated in the process of oral transmission. This is to miss the point of my argument. My model of crystallization does in fact allow for "modification and development." But the point is, such modification and development would have been gradually restricted in a process of crystallization. In terms of my argument, it is not the archaisms of Homeric poetry that would have been gradually eliminated, as Cairns supposes. Rather, the capacity of Homeric poetry to innovate was being

\footnotetext{
${ }^{85}$ Cairns 2001:3n12, citing Nagy 1996a and 1996b.

${ }^{86}$ Cairns 2001:4, citing Janko 1982:17, 192, 220-221; 1998:1, 11-12.

${ }^{87}$ Cairns 2001:3n12.
} 
gradually restricted over a period of two centuries in the process that I have been calling crystallization.

Although Cairns says that he agrees with Janko when it comes to the dating of Homeric textualization in the eighth century BCE, he actually disagrees with him when it comes to visualizing the form of this textualization: unlike Janko, Cairns posits a Homeric text that stems not from the dictation of an oral composition in the eighth century BCE but rather from the actual writing down of a composition by a literate poet ${ }^{88}$ In order to posit such an early date for Homeric textualization, however, Cairns must depend on the linguistic criteria developed by Janko in calculating a relative chronology for the dating of Homeric poetry. And such a dependence is questionable. Cairns does not reckon with the relevant additional linguistic criteria developed by Albio Cesare Cassio, who has argued against the dictation theory of Janko by demonstrating that the diction of Homeric poetry contains embedded linguistic features that extend from the eighth all the way into the sixth century $\{45 \mid 46\}$ BCE. ${ }^{89}$ This is not to question the linguistic criteria developed by Janko in calculating a relative chronology for dating Homeric poetry in comparison to, say, Hesiodic poetry. It is only to question Janko's dictation theory, which anchors the textualization of Homeric poetry in the eighth century BCE. ${ }^{90}$ As we see from the evidence collected by Cassio, the textualization of this poetry extended all the way into the sixth century BCE. ${ }^{91}$

By contrast, Cairns thinks that a "monumental poem" like the Homeric Iliad was composed as a text by a literate poet already in the eighth century BCE and that it was preserved all the way into the late sixth century BCE without any significant interference from "oral

\footnotetext{
${ }^{88}$ Cairns 2001:4.

${ }^{89}$ Cassio 1999:76-78; see also Cassio 2002:108.

${ }^{90}$ For a survey of other Homeric dictation theories, see Cassio 2002:108. For further debate about Janko's own dictation theory, see Nagy 2003:49-71.

${ }^{91}$ See especially Cassio 1999:81; 2002:117-118; see also Cerri 2010:94-96.
} 
transmission." Here is the way he puts it: "Given that oral transmission of the monumental poem prior to that date [that is, prior to the late sixth century $\mathrm{BCE}$ ] cannot explain the antiquity of the Iliad's diction, such a text [that is, a text stemming from the eighth century $\mathrm{BCE}]$ must have been a written one. ${ }^{"{ }^{2} 2}$ I question what he thinks is a "given" here, and I need to do so because it is precisely in this context that Cairns argues against my evolutionary or diachronic model for the making of Homeric poetry. In making his argument, he associates my model with the idea of Geoffrey Kirk concerning the Iliad as a "monumental poem" that was composed by an "oral poet" in the eighth century BCE and that somehow survived in an unwritten form until the late sixth century BCE. ${ }^{93}$ Cairns ignores here something I make clear in the same book that he criticizes for ideas that supposedly match Kirk's idea of the "monumental poem": the fact is, I have explicitly argued in that book against Kirk's idea that such a poem was created all at once in the eighth century BCE and was then somehow transmitted as a single creation, without significant changes, all the way into the sixth century. ${ }^{94}$

Kirk's idea is not all that far removed from the alternative idea preferred by Cairns, who thinks that the Homeric Iliad was composed as a written text in the eighth century BCE. ${ }^{95} \mathrm{I}$ propose to revisit that alternative idea one last time when I reach the end of my essay. $\{46 \mid 47\}$

\section{Transition}

Having defended the concept of Panhellenism as it applies to the Homeric Iliad and Odyssey, I can now pursue my overall argument that Homeric poetry shows a progressive loosening of ties to localized concerns about the cults of local heroes. As we will see, such a trend can be

\footnotetext{
${ }^{92}$ Cairns 2001:3-4.

${ }^{93}$ Kirk 1962.

${ }^{94}$ Nagy 1996b:110.

${ }^{95}$ Cairns 2001:4.
} 
seen as an aspect of Homeric Panhellenism, which shades over what is multiform-and therefore relatively more localized-as it highlights the uniformity of its own evolving unity.

And there are two sides to this overall argument. As we will also see, the unity of Homeric poetry, which is evident in the Iliad even more than in the Odyssey, promotes not only a loosening of ties to local hero cults. It promotes also a focusing on a single hero, Achilles, as the primary hero of cult, just as he is the primary hero of the epic that is the Iliad. To make this point, I will now proceed to analyze three sets of Homeric passages. Two of the sets are taken from the Iliad and one from the Odyssey. As we will see, all three sets of passages, even the one taken from the Odyssey, recognize the primacy of Achilles as a hero of cult.

\section{Three sets of Homeric passages showing references to hero cult}

In the three sets of passages I have selected, we will see implicit Homeric references to the practice of honoring heroes by way of hero cult. For the moment, I am not considering any explicit references, such as the mention in Iliad II 547-551 of seasonally recurring sacrifices made by the Athenians to their cult hero Erekhtheus. ${ }^{96}$ Such explicit references are peripheral to the main narratives of Homeric poetry, whereas the implicit references that I am about to analyze are all central to the unity of those main narratives. $\{47 \mid 48\}$

\section{Set One.}

Here I focus on Odyssey xxiv 80-84, a passage describing the tumulus that will be the tomb shared by Achilles and his dearest friend Patroklos:

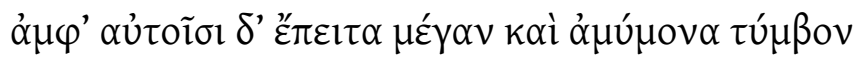

\footnotetext{
${ }^{96}$ On Erekhtheus in Iliad II 547-551, see Bravo 2009:14-15 and 27n29. Actually, this Homeric passage is a particularly complicated example of Homeric references to hero cults: for an incisive analysis of Iliad II 547-551 together with Odyssey vii 81, where we see another mention of Erekhtheus, see Frame 2009:395 and 445-446, with further references. The passages from Iliad II 547-541 and Odyssey vii 81 are both noted by Currie 2005:47.
} 


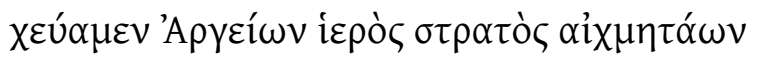

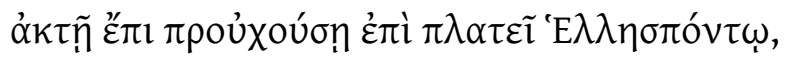

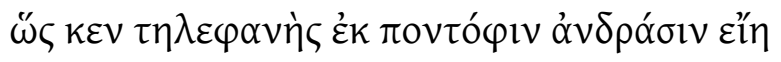

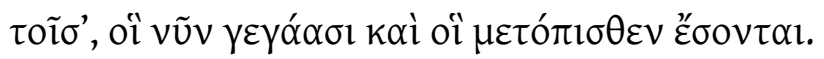

Next, over these [= the bones of Achilles and Patroklos], a great and faultless

tomb

was built by us the sacred band of Argive spearmen

on a promontory [aktē] jutting out over the vast Hellespont,

so that it might be visible, shining forth from afar, for men at sea [pontos],

both for those who live now and for those who will live in the future. ${ }^{97}$

Odyssey xxiv 80-84

The reference here in the Odyssey to the shared tomb of Achilles and Patroklos complements a set of stylized references to what is understood to be the same tomb in the Iliad (especially XIX 368-380; XXIII 125-126, 245-248)..$^{98}$ And the Homeric description of the tomb shared by these two heroes matches what we know about the tombs of cult heroes from sources external to Homeric poetry. ${ }^{99}$

\footnotetext{
${ }^{97}$ The time frame indicated as 'now' here is the era of the heroes who fought in the Trojan War, while the future is of course the ever movable here-and-now of Homeric reception. For a view of Homeric and also Hesiodic reception from the perspective of performance in the here-and-now, as conditioned by historical contingencies, see Nagy 2009a:274-275.

${ }^{98}$ Detailed analysis in Nagy 2009|2010 II §§50-89. As I point out in that analysis, it is made clear in XXIII 245-248 that the tomb to be shared by Achilles and Patroklos should be incomplete while only Patroklos occupies it, and that the final act of making the complete tomb must wait till the death of Achilles. That final act is what we see described in Odyssey xxiv 80-84. I should add that the setting of the tomb of Achilles and Patroklos, as primarily indicated by the word akte 'promontory' in Odyssey xxiv 82, is consistent with the setting for the funeral of Patroklos as described in the Iliad: here too the primary indicator is the same word akte, as we see in the contexts of XVIII 68, XXIII 125-126, XXIV 97.

${ }^{99}$ Nagy 1990b:220; in n52, there is an analysis of the relevant testimony of Pausanias 2.12.5.
} 
I show as an example one such external source, the Heroikos of Philostratus, who flourished in the early third century CE. In this work, Philostratus collected a vast array of details about hero cults, especially the $\{48 \mid 49\}$ cults attested in the region of Troy. Most relevant to my argument is his description of seasonally recurring sacrifices performed at the tomb of Achilles by Thessalian emissaries sent to Troy for the sacred purpose of renewing, in a stylized mode of ritual stealth, their ties to the final resting place of their native son (Heroikos 52.3-54.1). ${ }^{100}$

Such external evidence helps us see in a new light the relevant internal evidence of the Homeric Iliad. A case in point is the pervasive formulaic repertoire of Homeric references to the shelters in which Achaean heroes slept and dined and received guests when they were alive and fighting as warriors in the Trojan war: some of these references can be traced back to sacralized pastoral contexts referring to the final resting places of cult heroes. ${ }^{101}$

In Odyssey xxiv 35-98, which is the larger context that frames the description of the tomb shared by Achilles and Patroklos in Odyssey xxiv 80-84, we find that the narrative is pervaded by further references to the hero cult of Achilles. I offer here a brief inventory of some of these references:

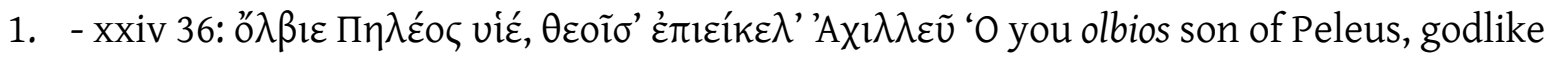
Achilles'. These words are spoken in Hades by the psukhē of Agamemnon (xxiv 35) in

\footnotetext{
${ }^{100}$ Nagy 2009|2010 II §§47-55, 86-89. See also the running commentary of Berenson and Aitken 2001:153-165. I also recommend the eclectic comments of Grossardt 2006 II 719-722, though I have to express my disagreement with his skeptical views concerning the historical value of the ritual details formulated by Philostratus.

${ }^{101}$ Nagy 2009|2010 II §§56-58, focusing on the Homeric uses of the words stathmos, klisia, sēkos. In another project (A Homer commentary in progress, by D. Frame, L. Muellner, and G. Nagy, forthcoming in Classics@), I study the relevance of these sacralized pastoral words to (1) the myth, as retold in the Ajax of Sophocles, about the deranged slaughtering of herds in the Troad by the hero Ajax, and (2) the hero cult of Ajax in the vicinity of Rhoiteion in the Troad and the references to this cult in the Heroikos of Philostratus (18.3-5), where we read that herdsmen in the Troad fear the damage that the angry spirit of Ajax can inflict on their herds (see Nagy 2001a:28n21). In the context of this same project, I study in general "the poetics of the angry cult hero" as reflected in such Homeric scenes as the killing of the suitors by Odysseus (with reference to Theognis 1123-1125, as analyzed by Nagy $1985 \S \S 68-70$ [= pp. 74-76]).
} 
response to the psukhe of Achilles (xxiv 24). For the moment, I translate psukhē as 'spirit' and olbios as 'fortunate'. As we will see later, however, both these words have $\{49 \mid 50\}$ deeper meanings, conveying the idea of heroic immortalization after death.

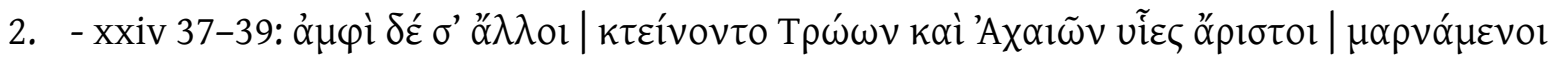
$\pi \varepsilon p i$ $\sigma \varepsilon \tilde{o}$ 'On all sides of you [= your corpse], the rest of them | were being slaughtered, sons of both Trojans and Achaeans, the best, | as they were fighting over you [= your corpse]'. The Achaeans and the Trojans are battling here over the possession of the corpse of Achilles ${ }^{102}$ The mentality of needing to possess the body of the dead hero, whether he was a friend or an enemy in life, is typical of hero cults, in that the corpse of the cult hero was viewed as a talisman of fertility and prosperity for the community that gained possession of the hero's body. ${ }^{103}$

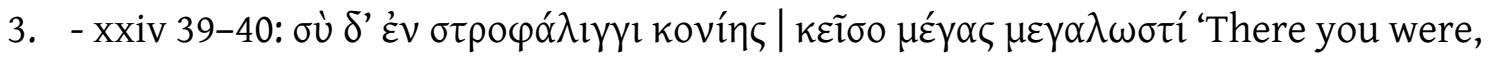
lying in a swirl of dust. | You lay there so huge in all your hugeness'. The corpse of Achilles is described here as larger than life. ${ }^{104}$ As we see from lore preserved in the historical period about cult heroes, they were conventionally pictured as far larger in death than they had been in life. ${ }^{105}$

\footnotetext{
${ }^{102}$ Narratives about this kind of battle are attested also in the visual arts. To cite just one example here, there is a Rhodian Black Figure plate, dated to the second half of the seventh century BCE (London, British Museum 1860,0404.1 A 749), showing the figures of Menelaos and Hector battling over the corpse of Euphorbos (see Bravo 2009:17).

${ }^{103}$ Nagy 1990a 1\$29, $6 \$ 59$ (= pp. 32, 178); $2006 \S 97$.

${ }^{104}$ This wording applies to Achilles also in Iliad XVIII 26-27, where he stages himself as a corpse in mourning the death of Patroklos and where he is mourned by Thetis as if he were already a corpse (BA $6 \$ 24$ [= p. 113], especially with reference to XVIII 71). At XVI 775-776, cognate wording applies to the corpse of the hero Kebriones. The corpse of Achilles is described as nine cubits long in the Alexandra of Lycophron (860).

${ }^{105}$ Survey by Brelich 1958:233-234. Among the striking examples in this survey is the corpse of Orestes as cult hero, described in Herodotus (1.68).
} 


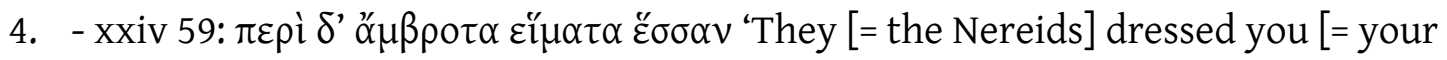
corpse] in immortalizing clothes'. At the funeral of Achilles, his divine mother and her sister Nereids dress the hero's corpse in 'immortalizing' clothes. ${ }^{106}$

5. - xxiv 73-77. After the cremation of the corpse of Achilles, his bones and those of the already cremated corpse of Patroklos are placed into $\{50 \mid 51\}$ a golden amphora that had been given by the god Dionysus to the goddess Thetis. This amphora, as we know from the comparative evidence of other poetic references (especially Stesichorus PMG 234), is a sign of the hero's immortalization after death. ${ }^{107}$

6. - xxiv 85-86. After the making of the tumulus which will be the tomb shared by Achilles and Patroklos (xxiv 80-84), funeral games are held in honor of Achilles. The details of this description match closely the details we can gather from historical evidence about athletic contests held in honor of cult heroes. ${ }^{108}$

7. - xxiv 91. The athletic contests at the funeral games of Achilles and the prizes to be won in these contests are instituted for the purpose of compensating for his death, and, in this verse, such an act of compensation is expressed by way of the prepositional phrase epi soi

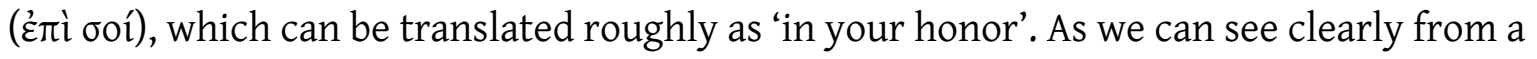
variety of prose sources, the syntactical construct combining the preposition epi with the dative case of a given hero's name refers to the cult of that hero. ${ }^{109}$

\footnotetext{
${ }^{106}$ On the vital importance of understanding ambrotos as 'immortalizing' as well as 'immortal', I refer to my argumentation in Nagy 1990b:141, with reference especially to Iliad XVI 670 and 680. I will have more to say later about these verses.

${ }^{107}$ BA $10 \$ 50$ (= p. 209); see also Dué 2001.

${ }^{108}$ BA $6 \$ 30$ (= pp. 116-117).

${ }^{109}$ Collection of evidence in Nagy 1990a $4 \S 7$ (= p. 121). Perhaps the most striking example is this entry in the

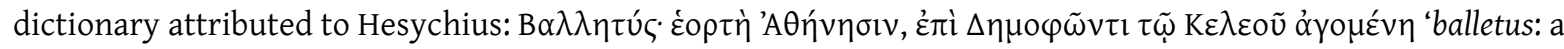
festival event at Athens, held in honor of Demophon son of Keleos' (further references to this athletic event of
} 


\section{Set Two.}

I focus here on Iliad XXIII 326 and 331, two verses concerning the sèma or 'sign' given by the hero Nestor to his son, the hero Antilokhos, about the sèma or 'tomb' of an unnamed cult hero.

The two verses come from an Iliadic narration of the instructions given by Nestor to Antilokhos about the driving skills required for a charioteer to make a left turn around a landmark. As we learn from the context, this landmark will be used as a turning post in the course of a chariot race that is being planned as the culminating athletic event of the Funeral Games for Patroklos in Iliad XXIII. In the words of Nestor, this landmark is either a sēma 'tomb' of an unnamed hero of the ancestral past (XXIII 331) or it was once upon a time a turning post, $\{51 \mid 52\}$ a nussa (332), used for chariot races that must have taken place in that ancestral past:

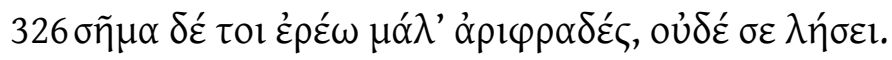

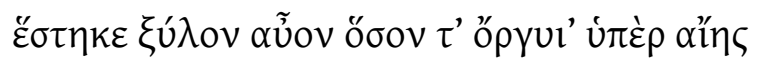

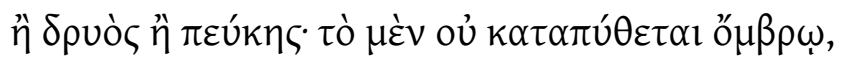

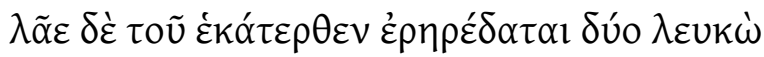

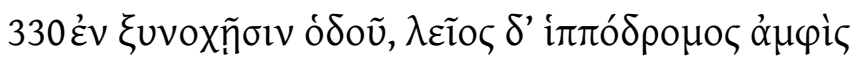

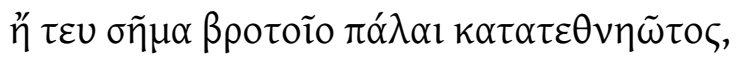

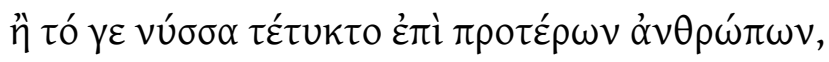

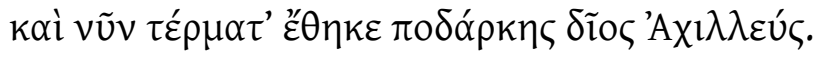

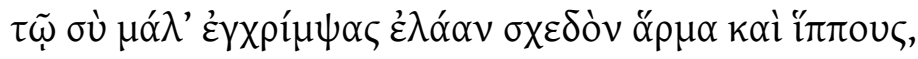

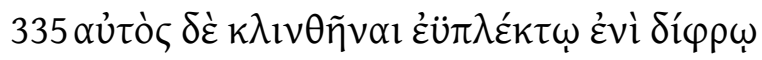

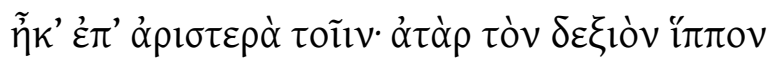

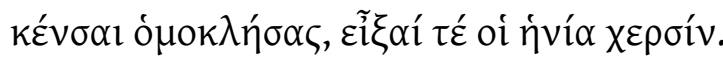

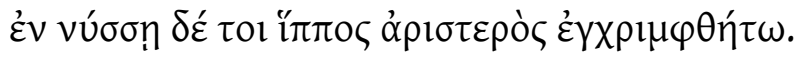

simulated warfare in 1990a 4§7n26). 
326 I [Nestor] will tell you a sign [sèma], a very clear one, and you will not let it get lost in your thinking.

Standing over there is a stump of deadwood, a good reach above ground level. It had been either an oak or a pine. And it hasn't rotted away from the rains. There are two white rocks propped against either side of it.

330 There it is, standing at a point where two roadways meet, and it has a smooth track on both sides of it for driving a chariot.

It is either the tomb [sēma] of some mortal who died a long time ago or was a turning post [nussa] in the times of earlier men. Now swift-footed radiant Achilles has set it up as a turning post [terma plural]. Get as close to it as you can when you drive your chariot horses toward it, 335 and keep leaning toward one side as you stand on the platform of your wellbuilt chariot, leaning to the left as you drive your horses. Your right-hand horse you must goad, calling out to it, and give the horse some slack as you hold its reins, while you make your left-hand horse get as close as possible to the turning-post.

Iliad XXIII 326-338

The semma that is the 'tomb' of the unnamed hero at verse 331 is also a 'sign' of that hero's cult, as signaled by the semma or 'sign' that is conveyed at verse 326 by the speaker. It is this particular context of sèma as 'sign' in verse 326 that motivates the title of my present essay, "Signs of Hero Cult in Homeric Poetry." As I show in an earlier essay, "Sēma and Noēsis: The Hero's Tomb and the 'Reading' of Symbols in Homer and $\{52 \mid 53\}$ Hesiod," ${ }^{110}$ we know from

\footnotetext{
${ }^{110}$ Nagy 1990b:202-222, a recasting of Nagy 1983a.
} 
evidence external to Homeric poetry that the tomb of a cult hero could be used as the actual turning post of a chariot race. ${ }^{111}$ In the Iliad, viewed from the standpoint of the overall narrative, the tomb of the unnamed hero from the past becomes the same thing as the turning post of a chariot race from the past. I say this because that past hero and that past chariot race become the present hero Patroklos and the present chariot race that will be held in Iliad XXIII to honor Patroklos as a cult hero. ${ }^{112}$

I focus on the left turn of the chariot that is pictured as racing around the turning post at verses 334-338 here in Iliad XXIII. ${ }^{113}$ This left turn can be seen as a ritual act of hero cult-once we recognize that the turning post here is being equated with the tomb of a cult hero in the narrative of the Iliad.

Such an equation, as we will see, is implicit in the Homeric Iliad. And it is implicit also in the iconographical evidence of a Black Figure vase painting. I have in mind here a picture painted on a hydria that is now housed in the museum of the university in Münster and dated to the late sixth century BCE by Klaus Stähler, who published the editio princeps of the Münster Hydria. ${ }^{114}$ In this picture we see the hero Achilles himself in the act of participating in the chariot race held in honor of Patroklos. The picture shows Achilles running on foot alongside his speeding chariot drawn by four horses and driven by his charioteer: the hero has jumped off the chariot, which is rounding the tomb that Achilles will be sharing with Patroklos. And the chariot is making a left turn around this tomb. As Stähler demonstrates, Achilles here is

\footnotetext{
${ }^{111}$ Nagy 1990b:215-216, with reference to Pausanias 6.20.15-19 and with further comments. Still further comments by Frame 2009:134 (with n31) and 163 (with n54). See also Sinos 1980:48-49.

${ }^{112}$ Nagy 1990b:215-222; further argumentation in 1990a 7§§11-16 (= pp. 208-212).

${ }^{113}$ On the elaborate poetics of describing the left turn in chariot racing, which requires a perfect combination of impulse and restraint for the successful execution of such a left turn, I am guided by the detailed analysis of Frame 2009:133, 144-149, 153-156, 162-166, 331.

${ }^{114}$ Stähler 1967.
} 
engaging in a ritual athletic event that can best be described as a special kind of chariot race: the rider of the chariot, standing next to the driver standing on the chariot platform, must at a given moment leap off the speeding chariot and "hit the ground running" in competition $\{53 \mid 54\}$ with other chariot riders, called apobatai 'those who step off' in the Athenian version of this athletic event. ${ }^{115}$ As Stähler also demonstrates, with reference to the painting on the Münster Hydria and to other paintings, what is being pictured here is the beginning of the hero cult of Patroklos. ${ }^{116}$ And the ritualized actions of Achilles, as we see from these paintings, show the way for the future observance of rituals of hero cult not only for Patroklos but even for Achilles himself. ${ }^{117}$

The evidence of these paintings meshes with the evidence of the overall narrative of the Iliad, where Patroklos earns the role of a ritual substitute of Achilles. ${ }^{118}$ This role makes Patroklos not only a body-double but even a story-double of the central hero of the Iliad, where things happen to Patroklos that would otherwise have happened only to Achilles. ${ }^{119}$ The most central of these happenings is the ritual death of Patroklos at the hands of the god Apollo in Iliad XVI, since this happening in the Iliad prefigures the death of Achilles beyond the Iliad. ${ }^{120}$ And there are also other such happenings in the Iliad where the role of Patroklos as a cult hero functions as a substitute for the corresponding role of Achilles. A case in point is the narration in Iliad XVII of the fighting between the Achaeans and the Trojans over the possession of the

\footnotetext{
${ }^{115}$ Stähler 1967:15, 32-33, 44. Also Nagy 1990b:94n50 and 220n54; further details in 2009b about the athletic event of the apobatai at the festival of the Panathenaia in Athens; still further details in 2009|2010 II §§90-111.

${ }^{116}$ Stähler 1967:32.

${ }^{117}$ Nagy 1990b:94n5 and 220n54, following the argumentation of Stähler as cited in the previous note.

${ }^{118}$ For an analysis of the role of Patroklos as the ritual substitute of Achilles in the Iliad: BA 2\$8, 17§4 (= pp. 32-34, 292-293).

${ }^{119}$ For a general overview of the role of Patroklos as both the ritual substitute and the narrative surrogate of Achilles in the Iliad: Nagy 2007:64-69.

${ }^{120}$ On this subject, I find the book of Lowenstam 1981 to be of lasting value.
} 
corpse of Patroklos after he is killed in Iliad XVI. Directly comparable is the fighting over the corpse of Achilles as we already saw it described in Odyssey xxiv (37-39).

In view of this centrality of Patroklos as the surrogate cult hero of the Homeric Iliad, it is vital to highlight here a detail we see in the picture of Patroklos as painted on the Münster Hydria. The hero, imagined here as a miniature body-double of Achilles, hovers mid-air over the tomb that he will share with Achilles. And, in this painting, Patroklos is labeled as psukhēe $(\Phi \Sigma \bigvee X E)$. A neutral translation of this word's meaning would be 'spirit', but the more basic meaning of psukhē is 'breath of $\{54 \mid 55\}$ life', which in the context of hero cults signals the vital force that departs from the body of the hero at the moment of death-only to be reunited with that body after a transition, through Hades, into a paradisiacal setting that I have already described as transcending the temporal and the spatial constraints of mortality. ${ }^{121}$ Such a mystical reunion of the body with the psukhe is the essence of heroic immortalization. ${ }^{122}$

This theme of immortalization is implicit in the overall use of the word psukhē in Homeric poetry. I emphasize that the theme is implicit, not explicit, and that the formulaic system of Homeric diction shows this implicitness by actually avoiding the use of psukhē in certain situations and by substituting alternative words like thumos and menos in these situations. ${ }^{123}$ One such situation is a set of Homeric scenes where a hero swoons, that is, where he loses consciousness but does not die: in such scenes, it can be said that a hero loses his psukhē when he swoons (as in the case of Sarpedon when he swoons in Iliad V 696), but it cannot be said that he wins back his psukhe when he comes to. ${ }^{124}$ If the hero were dead, then he would not come to. But if he is not dead, then he will come to, that is, he will revive. The point is, in Homeric

\footnotetext{
${ }^{121}$ Nagy 1990b:88-93, 115-116.

${ }^{122}$ Nagy 1990b:126n30, 142.

${ }^{123}$ Nagy 1990b:87-88, with references.

${ }^{124}$ Nagy 1990b:90, with references.
} 
scenes where we see a hero reviving after swooning, that is, where the hero regains consciousness after having passed out temporarily, the 'breath of life' that he regains cannot be expressed by way of the word psukhe, which can be used to express only the loss of consciousness at the moment of swooning or dying but not the regaining of consciousness at the moment of reviving. From the standpoint of Homeric diction, to say that the psukhe as the 'breath of life' is regained after reviving from swooning is evidently too close to saying that the hero will revive not only after swooning but even after dying. ${ }^{125}$

Such a pattern of avoidance cannot be explained as a "suppression," at least in the sense that we have already considered earlier, since this pattern is so deeply embedded in the formulaic system of Homeric poetry. Such depth of embeddedness indicates a lengthy period of evolution for this pattern. By contrast, the idea of a "suppression" that is personally initiated by a literate author who seeks to draw attention away from the theme of heroic immortalization could not account for the $\{55 \mid 56\}$ systematic pervasiveness that we see in this pattern of avoidance, which produces the effect of actually drawing attention to the theme of immortalization, rather than distracting from it. From a neounitarian point of view, this pattern of consistently avoiding references to the return of the psukhe to the body shows a pervasive recognition of the theme of immortalization within the entire formulaic system of Homeric poetry. To use this system, this langue, when you speak the parole of Homeric poetry is to recognize and even to accept the implicitness of heroic immortalization.

Just as the theme of heroic immortalization is implicit as a central theme in the Homeric Iliad, it is implicit also in the picture painted on the Münster Hydria. As I show in my essay "Sēma and Noēsis," already mentioned earlier, the painting on the hydria signals this theme not only by picturing the psukhe of Patroklos as it hovers over the tomb that he will be sharing

\footnotetext{
${ }^{125}$ Nagy 1990b:89-92.
} 
with Achilles but also by even labeling the picture, that is, by painting the consecutive letters $\Phi-\Sigma-Y-X-E$ to spell psukhē, where the act of painting these letters that spell out psukhē becomes a sêma or 'sign' in its own right. ${ }^{126}$ In the timelessness of the narrative created in this picture, Patroklos and Achilles share not only the same sēma or 'tomb' but even the same psukhē, as indicated by the sēma or 'sign' for the word psukhē.

Just as the act of painting the letters that spell out psukhē becomes a sèma or 'sign' in its own right, so also the act of painting the image that shows the tomb shared by Patroklos and Achilles becomes a sèma or 'sign' of the tomb. And in fact the word for 'tomb' is already sēma.

It is essential for my argument to repeat here the simple fact that sema is a Homeric word that means not only 'sign' but also 'tomb'. That is what we see in Iliad XXIII 331, where sēma refers to the 'tomb' of the unnamed cult hero. And we see the same word five verses earlier in Iliad XXIII 326, where it refers to the 'sign' given by Nestor to Antilokhos. When Nestor says the word for 'sign', he is already saying the word for 'tomb'. Just as the act of painting an image that shows the tomb shared by Patroklos and Achilles becomes a sèma or 'sign' of the tomb, so also the act of saying the word sêma as a 'sign' becomes a 'sign' of the tomb. And the unspecified tomb of the unnamed hero becomes the specific tomb of the hero named Patroklos, who will be sharing this tomb with the hero named Achilles. Thus the sign given by Nestor to his son Antilokhos is not just an unspecified sign about how to drive in $\{56 \mid 57\}$ any chariot race but rather a specific sign about how to be a successful driver in the chariot race to be held in honor of Patroklos.

Although the sign given by Nestor to Antilokhos in Iliad XXIII is specific to the chariot race to be held in honor of Patroklos, the actual interpretation of this sign about the best way to make a left turn around a hero's tomb is not specific but general, even mystical. For

\footnotetext{
${ }^{126}$ Nagy 1990b:220.
} 
Antilokhos, as the narrative of the actual chariot race in Iliad XXIII elaborates in detail, the sign of Nestor is not only a lesson in chariot driving. It is also a lesson in sound thinking about the management of any crisis in life and about the need to balance impulse and restraint. ${ }^{127}$ Even more broadly, the sign given by Nestor to Antilokhos is a lesson in life, and the traditional poetics of that lesson can extend far beyond the narrative of the Iliad itself. ${ }^{128}$

The question remains, what is mystical about the sign of Nestor? Here I return to the actual wording:

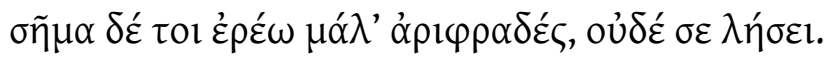

I will tell you a sign [sēma], a very clear one, and you will not let it get lost in your thinking

Iliad XXIII 326

As we have seen so far, Nestor's sēma for Antilokhos is a 'sign' of death as marked by the 'tomb' of an unnamed cult hero. But now we will see that this sèma is also a 'sign' of life after death, as marked by the same 'tomb'. ${ }^{129}$

The words spoken by Nestor to Antilokhos in the verse I just quoted again from Iliad XXIII 326 are matched exactly in Odyssey xi 126 (rephrased in xxiii 273). This verse in Odyssey xi 126 (rephrased in xxiii 273) is the beginning of a prophecy spoken by the psukhe of the seer Teiresias (xi 90, 150; xxiii 251), who appears to Odysseus during that hero's mystical sojourn in

\footnotetext{
${ }^{127}$ Nagy 1990b:216-219; Frame 2009:133, 144-149, 153-156, 162-166, 331.

${ }^{128}$ Nagy 1990a 7§§10-18 (= pp. 207-214). Here I analyze the sēma 'sign' given by Nestor to Antilokhos in Iliad XXIII 326 as pointing not only to the immediate epic narrative about the chariot race in honor of Patroklos but also to an ulterior epic narrative mentioned in the Proclus summary of the Epic Cycle (Aithiopis p. 106.4-6 ed. Allen; there is also a mention in Odyssey iv 186-188): in this narrative, best attested in a retelling by Pindar (Pythian 6.28-42), Antilokhos dies in a chariot fight, giving up his own life while saving the life of his father Nestor, whose chariot had been immobilized.

${ }^{129}$ I am expanding here on the argument I presented in Nagy 1990b:219.
} 
Hades. As I have argued in the essay "Sēma and Noēsis," the $\{57 \mid 58\}$ verses of the prophecy point to the future death of Odysseus and to the mystical vision of his own tomb, where he will be worshipped as a cult hero. ${ }^{130}$

Most revealing is the description of what will happen to people who find themselves in the

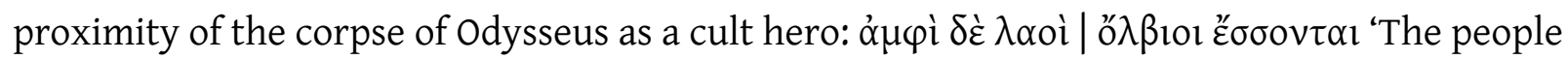
on all sides of you [= your corpse] will be olbioi' (xi 136-137, xxiii 283-284). Before we turn to the meaning of olbioi here, which I have left untranslated in this set of verses, I must briefly highlight an analogous set of verses describing the corpse of Achilles: $\alpha \dot{\alpha} \mu \grave{i} \delta \varepsilon \sigma^{\prime} \alpha^{\prime} \lambda \lambda_{o 1} \mid$

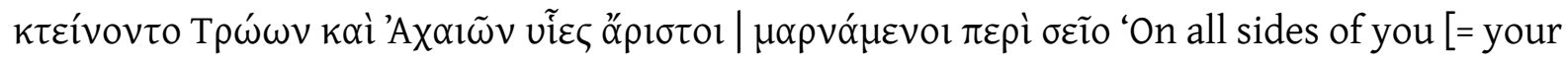
corpse], the rest of them / were being slaughtered, sons of both Trojans and Achaeans, the best, | as they were fighting over you [= your corpse]' (xxiv 37-39). Having noted this analogy, which touches on the idea of possessing the corpse of the cult hero, I can now turn to the meaning of the word olbioi describing those who find themselves in the proximity of Odysseus as cult hero (xi 137, xxiii 284). In the Hesiodic Works and Days (172) this same word olbioi describes cult heroes who are immortalized after death and who enjoy a state of bliss in a paradisiacal setting that transcends the temporal and the spatial constraints of mortality. ${ }^{131}$

In such a sacral context, the word olbioi means 'blessed' or 'blissful', and I argue that this same meaning applies also to ordinary humans who come into physical and even mental proximity with cult heroes by way of worshipping them. In the sacral context of such proximity, the worshippers can be at least momentarily blessed. By contrast, the cult heroes whom they worship are permanently blessed. But at least the worshippers experience a momentary transfer of bliss from the cult heroes. And there is another side to the argument:

\footnotetext{
${ }^{130}$ Nagy 1990b:212-214.

${ }^{131}$ Nagy 1990b:126, with further references.
} 
whereas the word olbioi can be rendered as 'blessed' or 'blissful' in such sacral contexts, in nonsacral contexts it can be rendered neutrally as 'fortunate'.

We see both meanings of olbios being used in the story of Herodotus (1.29-33) about the encounter of Croesus and Solon, where Croesus understands the word only in the non-sacral sense of 'fortunate' while Solon understands it also in the deeper sacral sense of 'blessed', referring to the blissful state of afterlife enjoyed by local cult heroes like Tellos of $\{58 \mid 59\}$ Athens and the brothers Kleobis and Biton of Argos. ${ }^{132}$ As the narrative of Herodotus implies, only those who are initiated into the mysteries of hero cult can understand the sacral meaning of olbios. This implication is evident in contexts where olbios refers to the bliss of initiation into mysteries of immortalization in general, as we see from the use of olbios with reference to the

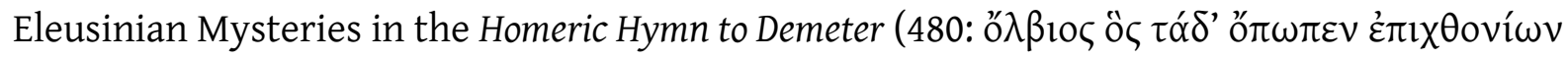

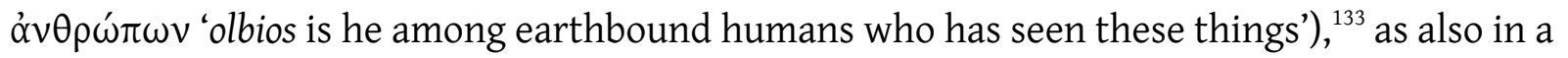

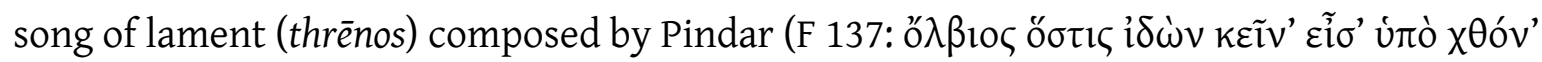
'olbios is he who has already seen those things when he goes below the earth'). ${ }^{134}$ Such contexts show that any initiate is olbios in the sense of 'blessed' only to the extent of knowing that you cannot achieve true blessedness before you experience death, which brings immortalization after death. As we can see from the wording of one of the "Orphic" gold leaves, only the immortalized dead can truly be addressed as olbioi (Orphicorum Fragmenta 488.9 ed. Bernabé: ő $\lambda \beta 1 \varepsilon \kappa \alpha i ̀ ~ \mu \alpha \kappa \alpha \rho ı \tau \tau \dot{)}$.

By now we can understand more clearly the point of the story of Herodotus about Croesus and Solon: only the initiated can understand the deeper meaning of the word olbios. And, it is important to add, only the initiated can understand the aphorism uttered by Solon: call no

\footnotetext{
${ }^{132}$ Nagy 1990a 8§§45-48 (= pp. 243-247).

${ }^{133}$ Nagy 1990a 8\$46n128 (= p. 245).

${ }^{134}$ Nagy 1990a $8 \$ 46$ (= pp. 245-246).
} 
man olbios until he is dead (Herodotus 1.32.8). That is, you cannot achieve a state of immortalization until after you are dead: until that time comes, you may be fortunate from one moment to the next but you cannot be truly olbios.

What holds for the worshippers of heroes holds also for the heroes themselves: heroes cannot be cult heroes until they are dead, and so they cannot be truly olbioi until they reach a blissful state of immortalization after death. So the word olbios is as yet ambivalent when the

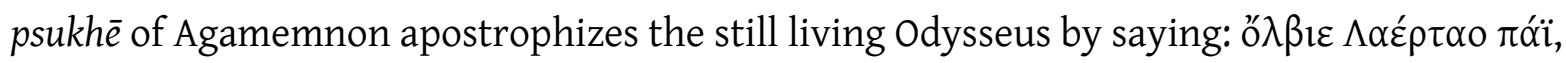

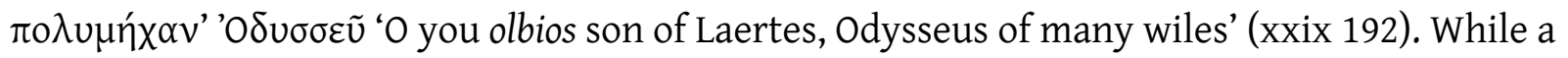
hero like Odysseus is still alive, he cannot have the word olbios as his permanent epithet. We see the same principle at work in the case of the hero Priam. Most telling are the words that

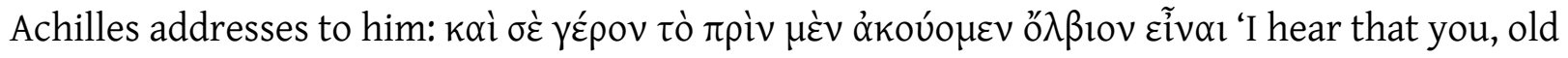
man, were once upon a time $\{59 \mid 60\}$ olbios' (Iliad XXIV 543). When Achilles is saying this to Priam, the old man is experiencing the worst moments of his life. He is neither fortunate nor blessed. Only after death could Priam ever become truly olbios.

These contexts of the word olbios are relevant to another context of the same word, which I

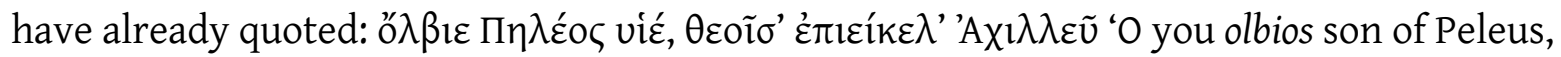
godlike Achilles' (xxiv 36). As we saw, the speaker here is the psukhe of Agamemnon (xxiv 35), and he is speaking to the psukhē of Achilles (xxiv 24). By now Achilles is already dead, already housed in his tomb, already a cult hero. In such a sacral context, the word olbios can be rendered as 'blessed' or 'blissful'.

In sum, we have seen that the word sêma, meaning both 'sign' and 'tomb' in verses 326 and 331 of Iliad XXIII, is a sign of hero cult. And we have seen the same double meaning of sēma in verse 126 of Odyssey xi (rephrased in xxiii 273). Here too, the sèma is a sign of hero cult. As I have argued, this word semma in Homeric diction signals not only the tomb of a cult hero but 
also the very act of signaling that tomb to those who are notionally initiated into the mystical language of hero cult. The double meanings of semma in the Iliad and Odyssey, as I have argued further, are central to the overall narratives of these two epics, which both recognize implicitly the theme of immortalization that we see being signaled by the signs of hero cult.

\section{Set Three.}

Here I focus on Iliad VII 85-86; XVI 456-457, 674-675, a set of three interrelated passages referring to heroic funerals.

The first of these three passages refers to the funeral and entombment of an unnamed Achaean warrior who must be Achilles from the standpoint of the overall narrative of the Iliad:

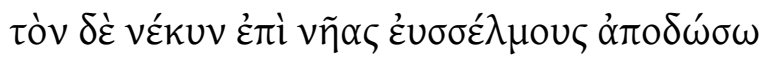

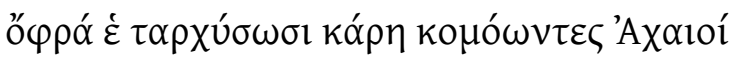

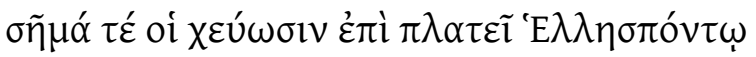

And I will give back his corpse, sending it back to their ships with the sturdy

benches, $\{60 \mid 61\}$

so that the Achaeans, they with their long hair, ${ }^{135}$ may ritually prepare $[\text { tarkhuein }]^{136}$ him

and that they may pile up for him a tomb [sèma] on the shore of the expansive Hellespont.

Iliad VII 84-86

\footnotetext{
${ }^{135}$ After the funeral of Achilles, the Achaeans will no longer wear their hair long: see Philostratus Heroikos 51.13. I propose that we see here an aetiology for the custom of wearing the hair short in the post-heroic age (Nagy $2009 \mid 2010$ II\$87).

${ }^{136}$ This translation of tarkhuein as 'ritually prepare' is a place-holder for the analysis that follows.
} 
In this passage, we see the same tomb that we already saw in the first of the three sets of Homeric passages I have chosen: it is the tumulus built on the Hellespont to house jointly the bodies of Achilles and Patroklos. And we see here also the same word sèma that we already saw in the second set of Homeric passages, where the word was referring to the tomb of Patroklos, soon to become the tomb of Achilles as well.

Short-range, something is wrong in the passage I just quoted. The words come from a speech of Hector, who is challenging whoever happens to be the best of all Achaean warriors to fight him in single combat: in Hector's wording, if he wins this fight and kills his Achaean opponent, then the corpse of that Achaean hero will be buried in a tomb built on the coast of the Hellespont (Iliad VII 84-91). ${ }^{137}$ Hector is of course wrong to think that he will kill the best of the Achaeans. In truth, it will be the other way around: it is Achilles, as the best of the Achaeans, who will kill Hector. Long-range, however, there is nothing wrong in this passage when it comes to the vision of the tomb that will be built to house the corpse of the best of the Achaeans on the coast of the Hellespont. That tomb will be the tumulus housing the corpse of Achilles himself (XXIII 125-126, 245-248), and so the unity of the Iliad will in the end straighten out the ongoing misapprehensions of Hector as one of its main characters. ${ }^{138}$

The second and the third of the three related passages in this third set of Homeric passages are identical to each other, both referring to the funeral and entombment of the hero Sarpedon in Lycia:

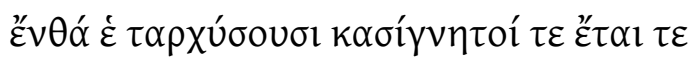

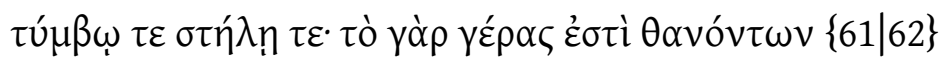

\footnotetext{
${ }^{137}$ BA 2\$3 (= pp. 28-29).

${ }^{138}$ BA 20§§22-24 (= pp. 340-343).
} 
And there [= in Lycia] his relatives and comrades will ritually prepare [tarkhuein] ${ }^{139}$ him,

with a tomb and a stele-for that is the privilege of the dead.

$$
\text { Iliad XVI 456-457 = 674-675 }
$$

As I have argued in an essay entitled "The Death of Sarpedon," ${ }^{140}$ all three of these Iliadic passages refer to a ritual preparing of the dead body for a mystical revivification after death. ${ }^{141}$ Once again we see the theme of heroic immortalization, which is as I argue a primary sign of hero cult. The word that refers to such immortalization in these three Homeric passages is tarkhuein ( $\tau \alpha \rho x u ́ \sigma o v \sigma r$ at VII 85, XVI 456, 674). So far I have been translating this word as 'ritually prepare', but the etymology shows a deeper meaning: as I argue, the Greek word tarkhuein is a borrowing from the Anatolian language that we know as Lycian, and the corresponding Lycian word conveys the idea of 'immortalize'.

The most relevant forms in the surviving corpus of Anatolian linguistic evidence are (1) Lycian Trqqñt-, name of a Lycian thunder god; (2) the cognate Luvian form Tarhunt-, name of the thunder god who is head of the Luvian pantheon; (3) the cognate Hittite form tarhu$/ \operatorname{tar}(r) u h-\left(/ \operatorname{tar} x^{\mathrm{w}}-/\right)$, a verb meaning 'be victorious, overcome' ${ }^{142}$ Cognates of this Hittite verb tarhu- in other Indo-European languages convey the idea of 'overcome' or 'transcend' in contexts where the object of transcendence is death itself. ${ }^{143}$ I argue that the Lycian and the

\footnotetext{
${ }^{139}$ As I said before, this translation of tarkhuein as 'ritually prepare' is a place-holder for the analysis that follows.

${ }^{140}$ Nagy 1990b:122-142, a recasting of Nagy 1983b.

${ }^{141}$ Nagy 1990b:139-142.

${ }^{142}$ Nagy 1990b:131-132. In what follows, I have more to say on the reconstruction of the Hittite form.

${ }^{143}$ Nagy 1990b:139. A shining example is the Greek compound noun nek-tar ( $\left.v \varepsilon ́ k \tau \alpha \rho\right)$, consisting of roots meaning 'death' (nek- as in nekros 'corpse') and 'conquer' (-tar, cognate with Hittite tarhu-); see Nagy 2008 (1972) 52-53. For more on -tar as in Greek nek-tar and its cognates in other Indo-European languages, see West 2007:158 and Watkins 1995:12, 346, 352, 391; in neither of these works can I find references to the relevant arguments in Nagy 1983b (recast in 1990b:122-142).
} 
Luvian names of the thunder god convey the idea of revivifying as well as overcoming, since thunder gods as described in Indo-European languages have the power to use their thunder weapons not only to $\{62 \mid 63\}$ overcome violently their enemies but also to preserve and thus make sacred their own devotees and even to revivify them. ${ }^{144}$

My linguistic argument that (1) the Greek word tarkhuein was a borrowing from the Lycian language and (2) the corresponding Lycian word stemmed from an Indo-European root conveying the idea that death can be overcome is supported by the fact that the Homeric narrative of the Iliad highlights the territory of Lycia as the place where the funeral and entombment of the hero Sarpedon will take place after he is killed by Patroklos. Not only that: according to the Homeric narrative, Lycia is also the native land of Sarpedon, where he rules as king. Here I find it most relevant to quote the formulation of Currie:

The fact that in the Iliad Sarpedon dies at Troy but is buried in Lycia is most easily explained on the assumption that Sarpedon already had a strong cultic association with Lycia. In that case, Sarpedon's hero cult at Xanthos in Lycia must antedate the Iliad even if the attestations of the cult are later. ${ }^{145}$

I agree with Currie's formulation, and I agree also with his observation that we can see "an apparent immortalization motif" in two further details of the Homeric narrative about the funeral and entombment of Sarpedon: (1) the hero's corpse is conveyed back to his native land of Lycia by the twins Hypnos and Thanatos (XVI 671-673 / 681-683) and (2) the god Apollo

\footnotetext{
${ }^{144}$ Nagy 1990b:197; see also pp. 140-141, 190 on the Greek noun, ēlusion, which can refer both to a place struck by a thunderbolt and to a place reserved for those who are immortalized after death.

${ }^{145}$ Currie 2005:50, with valuable references to secondary sources.
} 
himself anoints the corpse with ambrosia and dresses it in 'immortalizing clothes' (XVI 670 /

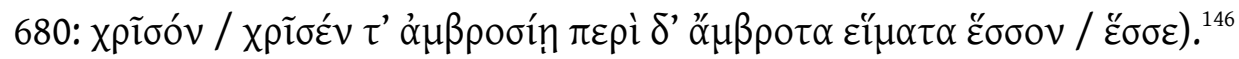

As a third example of "an apparent immortalization motif" in the Homeric narrative about the funeral and entombment of Sarpedon, Currie considers the proposed etymology of tarkhuein as a borrowing from the Lycian language and meaning 'immortalize' in an Anatolian cultural context, but then he backs away by saying: "this etymology $\{63 \mid 64\}$ is very uncertain." ${ }^{147}$ And, in any case, Currie thinks that the etymology of tarkhuein has no direct relevance to the plot of the Homeric Iliad. To quote his own words about tarkhuein, "it is used by Homer to mean no more than 'bury'."'148

In distancing himself from the etymological explanation of tarkhuein as meaning 'immortalize', Currie is relying on two different secondary sources that offer two different reactions to such an explanation: the first of these two sources simply rejects the proposed etymology by saying that Greek tarkhuein "is surely unrelated" to Hittite tarhu-, ${ }^{149}$ while the second source argues against the idea that the Greek word is a borrowing from Lycian and instead argues in favor of an alternative idea, that it can be traced back directly to a protoIndo-European form. ${ }^{150}$

\footnotetext{
${ }^{146}$ Currie 2005:51. On the basis of what I argue in my essay on Sarpedon (Nagy 1990b:141), I adjust from 'immortal' to 'immortalizing' Currie's translation (p. 51) of ambrotos. In my present essay, I have already referred to the

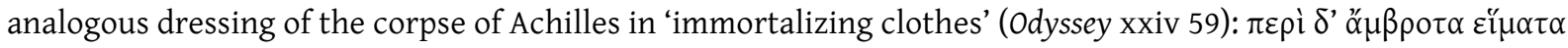
है $\sigma \sigma \alpha \nu$ 'they [= the Nereids] dressed you [= your corpse] in immortalizing clothes'.

${ }^{147}$ Currie 2005:51n32, citing Janko 1992:377 and Janda 1996; see also Currie 2006:33n146.

${ }^{148}$ Currie 2005:51.

${ }^{149}$ Janko 1992:337. He adds a related opinion, that Greek tarkhuein is also unrelated to tarikheuein, which he translates as 'pickle'. More on the word tarikheuein, from tarikhos, in Nagy 1990b:139n70; also 1990a 9§§28-35 (= pp. 269-273) and 2001a:18-19.

${ }^{150}$ Janda 1996:81-83, positing a proto-form *dhergh-. See also Bader 2001:35-36, who offers a similar argument but posits ${ }^{*}$ terh $_{2}$ - as the proto-form; further argumentation in Bader 2002.
} 
Neither one of these two sources persuades me. I pass over the first source, since all we see there is an opinion, without any argumentation. As for the second source, the argumentation is based on the assumption that the verb tarkhuein must be traced back to a Greek $u$-stem noun that must in turn be traced back further to a preexisting verb. ${ }^{151}$ This assumption, however, raises serious morphological and semantic questions: (1) how was the verb tarkhuein derived from a $u$-stem noun that looks like *tarkhu-, and (2) what would such a noun really mean if the verb that supposedly derives from it gets a meaning like 'bury'? I find that no one has answers to these questions.

But there is a way to explain the etymology of tarkhuein without having to posit an intermediate $u$-stem noun. Here I turn to my argument that the element tarkhu- in the Greek verb tarkhuein was borrowed from a corresponding element that we find in the Lycian noun Trqqñt-, which is the name of the Lycian thunder god. And the fact is, this noun Trqqñt- is not a u-stem noun. As Craig Melchert has pointed out to me in a personal communication, the stem of Lycian Trqqñt- must have $\{64 \mid 65\}$ been pronounced as something like /tark ${ }^{\mathrm{w}}$-/ and needs to be reconstructed as ${ }^{*}$ tar- $H^{\mathrm{w}}$-, which is the Anatolian stem we see at work in Hittite tarhu-, Luvian Tarhunt-, and so on; Melchert also points out that the Hittite verb tarhu- has a built-in extension in - $u-/-w_{-}$, as we see from such Hittite syllabic spellings as tar-hu-, ta(r)-ru-uh-, and tar-uh-. ${ }^{152}$

These facts enhance my argument that Greek tarkhuein is a borrowing from a preclassical Lycian form. The most economical explanation is to reconstruct a thematic noun stem ${ }^{*} t(e) r h^{\mathrm{w}}-$ o-, which in its Lycian form would mean something like 'victorious, overcoming, transcendent'.

\footnotetext{
${ }^{151}$ Janda 1996:80.

${ }^{152}$ Melchert to Nagy (personal communication 2011.02.15), revising his earlier views as published in Melchert 1994:306 (Janda 1996:80 based part of his argumentation on those earlier views). Melchert (same personal communication) agrees with Kloekhorst 2006: 97-101, who shows that the Hittite verb stem in question is / tarx $^{\text {w }}$ /, spelled alternately ta(r)ruh- / tarhu- (no ttarh- exists!), and that Lycian $q$ likewise represents a labialized velar.
} 
A factitive verb meaning 'make victorious, make transcendent' could then be derived from such a Lycian form. And, in view of the fact that the Lycian noun is the attested name of the thunder god of the Lycians, Trqqñt-, who is 'victorious, transcendent', the corresponding Lycian verb could have a sacred dimension in its meaning, that is, 'make (someone) victorious over death'-just as the god Trqqñt- makes someone victorious over death. I propose, then, that the Greek borrowing tarkhuein can be traced back to such a Anatolian verbal stem.

But how are we to imagine the specific details, as conveyed by the word tarkhuein, of the funeral of Sarpedon and of the funeral of Hector? So far, I have argued that the etymological sense of the word is 'immortalize', but I have been rendering the word as 'ritually prepare' in my working translations. So, in terms of my own argument, the question is this: how do you 'prepare ritually' the hero's corpse so as to immortalize it?

In search of an answer, I start by considering the context of tarkhuein in the wording of Hector. As we have already seen, Hector says that if he kills the unnamed hero who is best of all the Achaeans and strips that hero of his armor (VII 81-83), then he will give back the corpse of that hero to the Achaeans (84), who will 'ritually prepare' that corpse, as expressed by the word tarkhuein (85), and who will entomb it inside a tumulus built on the Hellespont (86). But Hector also says that if things turn out the other way, that is, if the unnamed hero kills him instead and strips him of his armor (77-78), then that hero will surely give $\{65 \mid 66\}$ back the corpse of Hector to the Trojans (79), who will then cremate the body of the Trojan hero (7980). So, in the wording of Hector, the 'ritual preparation' of the hero's corpse as expressed by the word tarkhuein (85) is understood to be the act of ritual cremation.

It has been argued, specifically with reference to the words of Hector as spoken in this passage, that the use of tarkhuein here shows the impossibility of deriving such a word from an Anatolian language like Lycian, since the words of Hector are referring here to the ritual 
procedures of the Achaeans, not of the Trojans ${ }^{153}$ In terms of such an argument, the question is: why would the Trojan Hector, as an Anatolian, use an Anatolian word in referring to the ritual of cremation as practiced by the non-Anatolian Achaeans?

I counterargue, from a neounitarian point of view, that the usage of Hector in this passage accords perfectly with the unity of the master narrative of the Homeric Iliad. The death and funeral of Achilles, culminating in the cremation of his corpse, are previewed from an Anatolian perspective in this passage. Even the death and funeral of the Trojan hero Hector, as narrated at length in Iliad XXIV, can be seen as an Anatolian preview of the death and funeral of Achilles as narrated ever so briefly in Odyssey xxiv. And the death and funeral of the Lycian hero Sarpedon, narrated even more briefly in Iliad XVI, can then be seen as yet another Anatolian preview, signaled by the word tarkhuein, of the death and funeral of Achilles as the central cult hero of Homeric poetry. ${ }^{154}$

In terms of my overall argumentation, the intensity of local color that we see in the details describing the death and funeral of a relatively more local hero like Sarpedon promotes a fuller appreciation of Achilles $\{66 \mid 67\}$ as the far more Panhellenic hero of the Homeric Iliad. ${ }^{155}$ And some of this local color can even spill over from the epic past into the cultic present. As

\footnotetext{
${ }^{153}$ Janda 1996:81; a similar argument is offered by Bader 2001:35n27.

${ }^{154}$ Of special interest is the fact that the god Apollo is directly involved in the ritual preparation of the corpse of Sarpedon in Iliad XVI: as we have already seen, Apollo himself anoints the corpse with ambrosia and dresses it in

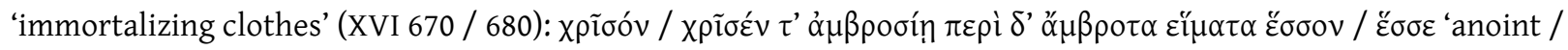
anointed him with ambrosia and dress /dressed him in immortalizing clothes'. In this context, then, Apollo is an Anatolian god, matching the Anatolian hero Sarpedon. By contrast, it is the Nereids who dress the corpse of

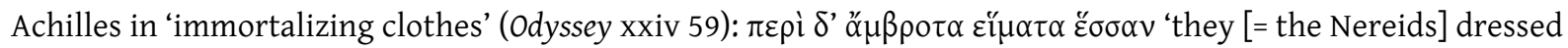
you [= your corpse] in immortalizing clothes'. In terms of Hector's prediction about the death and funeral of the best of the Achaeans and about his own death and funeral (VII 77-91), Apollo figures as the divine protector of Hector (VII 81, 83). And it is Apollo who protects the corpse of Hector from disfigurement and decay, even after it has been dragged behind the chariot of Achilles (XXIV 18-21).

${ }^{155}$ I argue this point at length in Nagy 1990b:132-136, with special reference to the Homeric use of the word dèmos as indicating a local community that has its own ritual practices in particular and its own customary laws in general.
} 
we will now see, the epic hero Sarpedon who lives and dies in the Iliad can find a way to speak about the cult hero Sarpedon who is worshipped by the people of Lycia. ${ }^{156}$ Here is how Sarpedon says it, addressing another Lycian epic hero named Glaukos, to whom he speaks not only as a royal companion but also as a fellow cult hero:

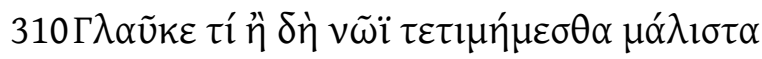

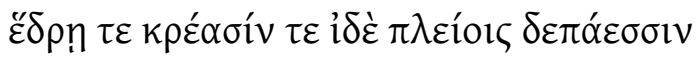

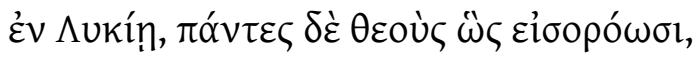

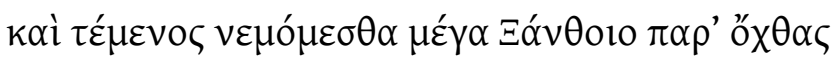

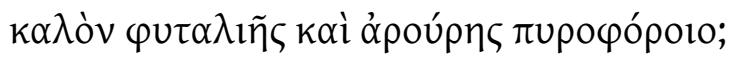

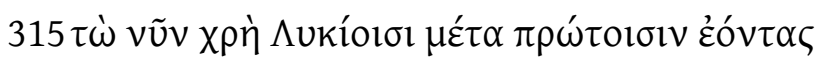

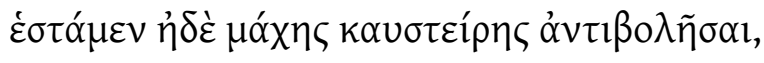

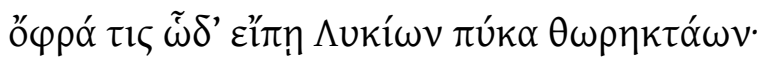

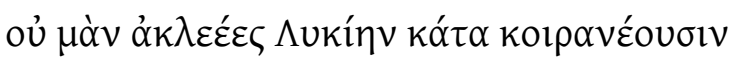

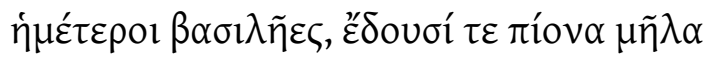

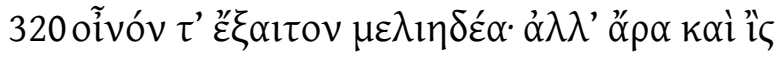

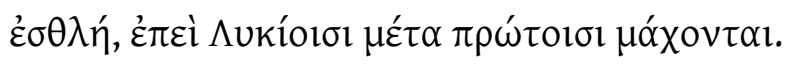

310 Glaukos, why is it that you and I get the most honor [verb timân] ${ }^{157}$ of all, with a special place to sit, with choice meats, and with full wine-cups in Lycia, and everyone looks at us as gods, and we are allotted a great sector of land [temenos] at the banks of the Xanthos,

\footnotetext{
${ }^{156}$ For an essay on the capacity of Homeric poetry to maintain contact between the past that is narrated by epic and the present that is recognized by epic performance, see Nagy 2001b (this essay includes an analysis of the relevant theories of M. M. Bakhtin).

${ }^{157}$ The verb timân and the noun time e can be used in Homeric diction as markers of the 'honor' that is given to local cult heroes. See Nagy 1990b:132-138, with reference to this passage and to other related passages.
} 
fine land, orchard and wheat-bearing plough land?

315 And so it is our duty to take our stand in the front ranks of the Lycians, and to meet blazing battle head-on, so that one of the heavily-armored Lycians may say of us: "Indeed it is not without glory [kleos] that our kings

are lords of Lycia, who feed upon fat sheep $\{67 \mid 68\}$ and drink choice sweet wine, since they have genuine strength and since they fight in the front ranks of the Lycians."

Iliad XII 310-321

I comment at length about this passage in my essay "The Death of Sarpedon," and here I quote only my summary, supplemented by further comments that I have integrated into the original footnotes of the essay (the original numbers of these footnotes are enclosed in square brackets): ${ }^{158}$

On one level, the examples of timē recounted by Sarpedon to Glaukos can function as attributes of a living epic hero who happens to be a king; on another level, however, each example can be matched with a corresponding sacral honor accorded to a cult figure. As we know from Greek religious practices attested in the historical era, cult heroes receive libations, ${ }^{[6] 159}$ choice cuts of

\footnotetext{
${ }^{158}$ Nagy 1990b:137-138.

${ }^{159}$ In my original footnote 63, I cited Burkert 1985:194, 205. More now on wine as a libation for cult heroes (as opposed to and in some cases in combination with other liquids used in libation: the blood of sacrificial animals, water, milk, honey, oil) in Ekroth 2002:67-68, 70, 75, 139, 254, 278. Of special interest is the analysis by Ekroth (pp. 178, 191-192, 206) of the reference in Pindar Olympian 1.90-92 to the drinking of the blood of sacrificial animals by Pelops as cult hero, which is drawn into a parallel with the drinking of wine by Hieron and his fellow symposiasts. I agree with the argument of Currie $(2005: 75,301,353)$ that the parallelisms between Pelops and Hieron in Pindar's Olympian 1 are meant as a poetic prophecy: once Hieron dies, he too will be a cult hero in his own right, like Pelops. Also of interest is the analysis by Ekroth (pp. 210, 235-237, 245n139) of relevant wording in an
} 
meat placed on a special table, ${ }^{[64] 160}$ and the allotment of a temenos in the sense of a 'sacred precinct ${ }^{[65] 161}\{68 \mid 69\}$

As we see from this passage, then, Homeric poetry can in fact refer to its characters as if they were already cult heroes.

\section{Conclusions}

I have considered three sets of Homeric passages where I find implicit references to the cult of heroes. Comparable are four sets of similar Homeric passages considered by Currie. ${ }^{162}$ Although there is no space for making any further arguments here, I would be ready to say that all four of Currie's sets of passages could be counted as examples of implicit references to hero cult.

inscription dated to the mid-fifth century BCE and found at Selinous (SEG 43.630) concerning correct procedures for sacrificing to ancestral cult figures called tritopatores (I offer comments on the meaning of this word in Nagy

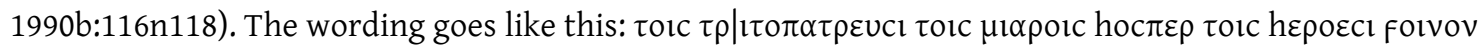
טло $\lambda \mathrm{h} \varepsilon \mathrm{l} \mid \psi \alpha \mathrm{c} \delta \mathrm{l}$ ' орочо 'sacrifice to the polluted tritopatores as to the heroes, pouring wine as libation through the covering [of the sacred place]' (column A lines 9-11 ed. Jameson, Jordan, and Kotansky 1993). Whereas one

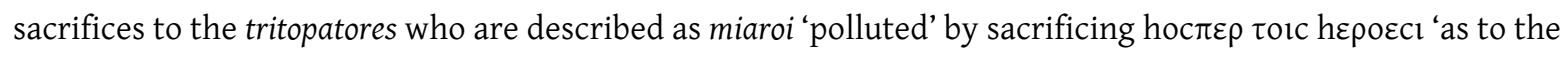
heroes' (column A line 10), things are different with the tritopatores who are not described that way: to them one

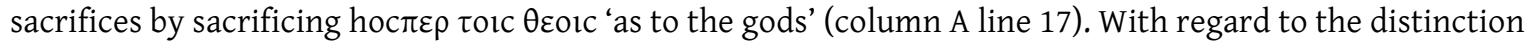
between 'polluted' and unpolluted tritopatores, corresponding to the distinction between worshipping heroes and gods, I compare the further distinction between the verbs en-agizein and thuein, which refer to the worshipping of heroes and gods respectively. In my analysis of the verb en-agizein in Nagy $2006 \$ 90$, I argue that it can be interpreted literally as 'take part in the pollution'.

${ }^{160}$ In my original footnote 64, I cited Gill 1974 on trapezōmata; I also noted: "Sarpedon's royal diet of mutton (Iliad XII 319) may be correlated with archaeological discoveries at Eretria showing that sheep are the usual victims sacrificed to heroes" (see Hadzisteliou Price 1973:136). More now on trapezōmata in Ekroth 2002:140, 281, 319.

${ }^{161}$ In my original footnote 65, I cited Burkert 1985:84-87 on temenos in the sense of 'sacred precinct'; on the precincts of Pelops and Pyrrhos as cult heroes, see Burkert 1983:93-103 and 119-120 respectively. More now on temenos in Ekroth 2002:36, 133n13, 143n72, 149, 183 (with reference to Herodotus 5.67), 186 (with reference to Euripides Erekhtheus F 65.87 ed. Austin), 200n316, 240, 334n88.

${ }^{162}$ The four sets of Homeric passages that are analyzed by Currie 2005:57 as examples of references to cult heroes involve the following heroes: (1) Sarpedon in Lycia, Iliad XVI 431-461, 666-683; (2) Odysseus in Ithaca, Odyssey xiii 96-112, 345-371; (3) Phrontis at Sounion, Odyssey iii 278-285; (4) Nausithoos in Scheria, Odyssey vi 3-12. In the case of Phrontis, Currie's references to the comments of Kearns 1989 and Antonaccio 1995 are especially useful. I recommend the further comments of Bravo 2009:25 (with regard to the image 14935: Athens, National Archaeological Museum). In the case of Nausithoos, I recommend the further analysis of Frame 2009:245, 247, 276. 
And I include in this count his first set, which overlaps with my third set featuring the two Iliadic passages that refer to the death and funeral of the hero Sarpedon.

What I have been describing here as implicit references to hero cult corresponds to a pattern of "suppression" that Currie sees at work in the Iliad and Odyssey. For Currie, as we have seen, such a pattern was shaped by an individual author's way of thinking. So, the four sets of Homeric passages where Currie sees references to hero cult are viewed as exceptions to a prevailing pattern of authorial thought. As I have argued, $\{69 \mid 70\}$ however, the "suppression" of Homeric references to hero cult can be understood in a broader sense. It is not that an individual author's way of thinking suppresses thoughts of worshipping the hero after death. Rather, the entire formulaic system of the Iliad and Odyssey tends to "suppress" the overt expression of such thoughts, that is, to leave them implicit. If Currie is ready to accept such a broader understanding of "suppression," then I in turn am ready to accept his term.

And I offer him reassurances about my use of the term formulaic system: when I speak of the workings of such a system in Homeric poetry, I have no intention of depersonalizing that poetry. In the parole of Homeric performance, the thinking of the persons who spoke and heard the langue of Homeric poetry can come back to life for us every time we read that parole as recorded in the surviving Homeric texts. Every time, that thinking will be ready to engage with us in any and all aspects of Homeric narration. But that thinking needs to be analyzed diachronically as well as synchronically, since the langue of Homeric poetry kept on changing in the course of its lengthy evolution. The parole of each new performance was an instance of change.

In the evolving langue of an evolving formulaic system in Homeric poetry, the progressive loosening of ties to localized concerns about local hero cults resulted in the general avoidance of explicit references to these cults not only on the level of narrating the actions of heroes but 
even on the more basic level of referring to the heroes themselves as cult heroes. That is why, I must now add, there are no explicit references to hero cult in Homeric contexts where we see the word hērōs 'hero' being used. ${ }^{163}$

Still, a diachronic analysis of the formulaic uses of this word in Homeric poetry reveals indications of the concept of hero cult. These indications are embedded in the formulaic system of Homeric poetry. A case in point is the formulaic association of the noun hērōs 'hero' with the noun Hērā, name of the goddess Hera. ${ }^{164}$ This association extends to the noun hōrā, meaning 'season' or 'seasonality', which is used in contexts describing Hera as the goddess of the seasons, as seasonality personified; it $\{70 \mid 71\}$ is no accident that Homeric poetry shows Hera being attended by the seasons personified, the divine Hōrai (Iliad V 749, VIII 393, 433). ${ }^{165}$ And this noun hōrā can refer directly to the seasonal recurrence of occasions for worshipping cult heroes (as in the Homeric Hymn to Demeter 265). ${ }^{166}$

There is an etymological connection of the noun hērōs with the nouns hōrā and Hērā, which is central for understanding the convergences and divergences between cult heroes and epic heroes: basically, the idea of a hero's unseasonality in life, as narrated in epic, is organically related to the idea of that same hero's seasonality in death, as realized in hero cult. ${ }^{167}$ I find it most telling that the central hero of the Homeric Iliad, Achilles, describes himself in Iliad XXIV 540 as pan- $a-(h) \overline{o r}$-ios 'the most unseasonal of them all'. ${ }^{168}$ And the model for this heroic

\footnotetext{
${ }^{163}$ Currie 2005:60 notes that the attestations of hērōs in the Homeric Iliad and Odyssey show no direct indications of hero cult. Reading his analysis, I do not find it probative that this word hērōs is used by Homeric heroes in addressing each other and in talking to each other. As I have already argued, Homeric narrative allows its heroes to refer to each other as if they were already cult heroes.

${ }^{164}$ Nagy 2008 (1972) 50-52.

${ }^{165}$ Nagy 1996b:48n79, 2001a:28n21.

${ }^{166}$ Nagy 1990a $5 \S 7$ (= p. 140), 1990b:136; $2006 \$ 107$.

${ }^{167}$ Nagy 1996b:47-48, referring also to BA 10§\$10-13 (= pp. 181-184).

${ }^{168}$ Nagy 1996b:48.
} 
untimeliness of Achilles is the story of Herakles as retold in Iliad XIX 95-133, which goes to the very core of the concept of the cult hero. ${ }^{169}$ The story of Herakles gets retold even in the name Hêrakless 'he who has the glory [kleos] of Hera', which marks both thes medium and the message of the cult hero. ${ }^{170}$

I conclude, then, from the Homeric passages I have analyzed that hero cult was not only a reality for Homeric poetry but also an integrating principle in the formation of this poetry. I reached this conclusion by applying a diachronic approach to the oral traditions that shaped Homeric poetry, and it is this approach that I describe as neounitarian. ${ }^{171}$

\section{Bibliography}

Albersmeier, S., ed. 2009. Heroes: Mortals and Myths in Ancient Greece. Baltimore.

Allen, T. W. 1912. ed. Homeri Opera V (Hymns, Cycle, fragments). Oxford.

Antonaccio, C. M. 1995. An Archaeology of Ancestors: Tomb Cult and Hero Cult in Early Greece. Lanham MD.

Bader, F. 2001. "Une traversée menée à terme: Noms de conquérants i.e. en étrusque (Pélasges, Tyrrhènes, Tuscī, Etruscī, Tarkhōn, Tarquin)." Studia Indo-Europea 1:31-53.

Bader, F. 2002. "L'immortalité des morts." Donum grammaticum: Studies in Latin and Celtic Linguistics in Honour of Hannah Rosén (ed. L. Sawicki and D. Shalev) 11-28. Leuven.

\footnotetext{
${ }^{169}$ Nagy 1996b:47.

${ }^{170}$ On the linguistic and thematic background for the etymology of Hēraklēs: Nagy 2006 §106, with references.

${ }^{171}$ I prefer this adjective to "oralist," as used by Cairns 2001:53, who thinks that "oralists" have by now been made obsolete by Classicists who take "familiar" approaches to Homeric poetry: "So much has the tide turned, in fact, that the onus is now on oralists to demonstrate that there is any significant way in which the status of the Iliad as an oral-derived text precludes or limits the application of familiar interpretative strategies." In response to this way of thinking, I confine myself to observing that familiarity can lead to a narrowing rather than a broadening of perspectives. I sense that such a narrowing is taking place when I read the reaction expressed by Cairns ( $p$. 36n121) to my neounitarian explanation of the dual forms used in the embassy scene of Iliad IX (Nagy 1996b:138145, expanding on BA ch. 3): he describes this explanation in one word, "incredible." His own explanation (Cairns pp. 35-36), which posits a rewriting of a preexisting written text, is offered in the context of clarifications about what it means to be a "neoanalyst."
} 
Bakker, E. 2005. Pointing at the Past: From Formula to Performance in Homeric Poetics. Hellenic Studies 12. Cambridge MA and Washington DC.

Berenson Maclean, J. K., and Aitken, E. B. 2001. eds. Flavius Philostratus, <<Heroikos >>. Atlanta GA.

Bravo, J. J. 2009. "Recovering the Past: The Origins of Greek Heroes and Hero Cults.” In Albersmeier 2009:10-29.

Brelich, A. 1958. Gli eroi greci: Un problema storico-religioso. Rome.

Burkert, W. 1983. Homo Necans: The Anthropology of Ancient Greek Sacrificial Ritual and Myth (translated by P. Bing). Berkeley and Los Anteles. Originally published 1972 as Homo Necans. Berlin.

Burkert, W. 1985. Greek Religion (translated by J. Raffan). Cambridge MA. Originally published 1977 as Griechische Religion der archaischen und klassischen Epoche. Stuttgart.

Cairns, D. L. 2001. Introduction. Oxford Readings in Homer's <<Iliad>> (ed. D. L. Cairns) 1-56. Oxford.

Cassio, A. C. 1999. "Epica greca e scrittura tra VIII e VII a.C.: madrepatria e colonie d'occidente." Atti del Convegno "Scritture mediterranee tra il IX e il VII secolo a.C." (eds. G. Bagnasco Gianni and F. Cordano) 67-84. Milan.

Cassio, A. C. 2002. "Early Editions of the Greek Epics and Homeric Textual Criticism in the Sixth and Fifth Centuries BC." Omero tremila anni dopo (ed. F. Montanari) 105-136. Rome.

Cerri, G. 2010. “Théorie de l'oralité et analyse stratigraphique du texte homérique: le concept de "poème traditionnel'." Gaia: Revue interdisciplinaire sur la Grèce archaïque 13:81-106.

Chantraine, P. 2009. Dictionnaire étymologique de la langue grecque: histoire des mots (ed. J. Taillardat, O. Masson, and J.-L. Perpillou), with a supplement Chroniques d'étymologie grecque 1-10 (ed. A. Blanc, Ch. de Lamberterie, and Jean-Louis Perpillou). Paris. Abbreviated DELG.

Currie, B. G. F. 2003. Review of Ekroth 2002. Journal of Hellenic Studies 123:238-241.

Currie, B. G. F. 2005. Pindar and the Cult of Heroes. Oxford.

Currie, B. G. F. 2006. "Homer and the Early Epic Tradition." Epic Interactions: Perspectives on Homer, Virgil, and the Epic Tradition Presented to Jasper Griffin by Former Pupils (ed. M. J. Clarke, B. G. F. Currie, and R. O. A. M. Lyne) 1-45. Oxford. 
Dué, C. 2001. “Achilles' Golden Amphora in Aeschines' Against Timarchus and the Afterlife of Oral Tradition." Classical Philology 96:33-47.

Ekroth, G. 2002. The Sacrificial Rituals of Greek Hero-Cults in the Archaic to the Early Hellenistic Periods. Liège.

Ekroth, G. 2009. “The Cult of Heroes.” In Albersmeier 2009:121-143.

Frame, D. 2009. Hippota Nestor. Hellenic Studies 37. Cambridge MA and Washington DC.

Gill, D. 1974. "Trapezomata: A Neglected Aspect of Greek Sacrifice." Harvard Theological Review 67:117-137.

Grossardt, P. 2006. Einführung, Übersetzung und Kommentar zum <<Heroikos $>>$ von Flavius Philostrat I/II. Schweizerische Beiträge zur Altertumswissenschaft 33. Basel.

Hadzisteliou-Price, T. 1973. "Hero-Cult and Homer." Historia 22:129-144.

Jakobson, R. 1990. On Language (ed. L. R. Waugh and M. Monville-Burston). Cambridge MA.

Jameson, M. H., Jordon, D. R., and Kotansky, R. D. 1993. A lex sacra from Selinous. Greek Roman and Byzantine Studies Monographs 11. Durham NC.

Janko, R. 1982. Homer, Hesiod and the Hymns: Diachronic Development in Epic Diction. Cambridge. Janko, R. 1992. The Iliad: A Commentary. Vol. 4, Books 13-16. Cambridge.

Janko, R. 1998. “The Homeric Poems as Oral Dictated Texts.” Classical Quarterly N.S. 48:1-13.

Jones, B. 2010. "Relative Chronology within (an) Oral Tradition." Classical Journal 105:289-318.

Kearns, E. 1989. The Heroes of Attica. London.

Kirk, G. S. 1962. The Songs of Homer. Cambridge.

Kloekhorst, A. 2006. "Initial Laryngeals in Anatolian." Historische Sprachforschung 119.77-108.

Larson, J. 2009. “The Singularity of Herakles." In Albersmeier 2009:32-38.

Lloyd-Jones, H. 1983. The Justice of Zeus. 2nd ed. Berkeley.

Lord, A. B. 1960. 2nd ed. 2000, edited and with introduction by S. Mitchell and G. Nagy (pp. viixxix). The Singer of Tales. Harvard Studies in Comparative Literature 24. Cambridge MA.

Lowenstam, S. 1981. The Death of Patroklos: A Study in Typology. Beiträge zur Klassischen Philologie 133. Königstein. 
Martin, R. P. 1989. The Language of Heroes: Speech and Performance in the Iliad. Ithaca.

Melchert, H. C. 1994. Anatolian Historical Phonology. Amsterdam / Atlanta.

Muellner, L. 1996. The Anger of Achilles: Mênis in Greek Epic. Ithaca NY.

Nagy, G. 1972. Introduction, Parts I and II, and Conclusions. Greek: A Survey of Recent Work (F. W. Householder and G. Nagy) 15-72. Janua Linguarum Series Practica 211. The Hague.

Nagy, G. 1979. The Best of the Achaeans: Concepts of the Hero in Archaic Greek Poetry. Revised ed. with new introduction 1999. Baltimore. Also available online at http://www.press.jhu.edu/books/nagy/BofATL/toc.html .

Nagy, G. 1983a. "Sēma and Noēsis: Some Illustrations." Arethusa 16:35-55. Recast as ch. 8 of Nagy 1990b.

Nagy, G. 1983b. "On the Death of Sarpedon." Approaches to Homer (ed. C. A. Rubino and C. W. Shelmerdine) 189-217. Recast as ch. 5 of Nagy 1990b.

Nagy, G. 1985. “Theognis and Megara: A Poet's Vision of His City.” Theognis of Megara: Poetry and the Polis (eds. T. J. Figueira and G. Nagy) 22-81. Baltimore. Also available online at http://www.press.jhu.edu/books/nagy/PHTL/toc.html .

Nagy, G. 1990a. Pindar's Homer: The Lyric Possession of an Epic Past. Baltimore MD. Also available online at http://www.press.jhu.edu/books/nagy/PHTL/toc.html .

Nagy, G. 1990b. Greek Mythology and Poetics. Ithaca NY. Also available online at http://chs.harvard.edu/publications/.

Nagy, G. 1996a. Poetry as Performance: Homer and Beyond. Cambridge. Also available online at http://chs.harvard.edu/publications/.

Nagy, G. 1996b. Homeric Questions. Austin TX. Also available online at http://chs.harvard.edu/publications/.

Nagy, G. 2001a. "The Sign of the Hero: A Prologue." In Berenson Maclean and Aitken 2001:xvxxxv. The page numbering will be given here in arabic numerals. Also available online at http://chs.harvard.edu/publications/.

Nagy, G 2001b. "Reading Bakhtin Reading the Classics: An Epic Fate for Conveyors of the Heroic Past." Bakhtin and the Classics (ed. R. B. Branham) 71-96. Evanston IL. Also available online at http://chs.harvard.edu/publications/. 
Nagy, G. 2002. Plato's Rhapsody and Homer's Music: The Poetics of the Panathenaic Festival in Classical Athens. Cambridge MA / Athens. Also available online at http://chs.harvard.edu/publications/.

Nagy, G. 2003. Homeric Responses. Austin TX.

Nagy, G. 2005a. “The Epic Hero.” A Companion to Ancient Epic (ed. J. M. Foley) 71-89. Oxford.

Nagy, G. 2005b. "An Apobatic Moment for Achilles as Athlete at the Festival of the Panathenaia." Imeros 5:311-317.

Nagy, G. 2006. Online and fuller version of Nagy 2005a, with notes, http://chs.harvard.edu/publications/.

Nagy, G. 2007. "Homer and Greek Myth.” The Cambridge Companion to Greek Mythology (ed. R. D. Woodard) 52-82. Cambridge. Also available online at http://chs.harvard.edu/publications/.

Nagy, G. 2008. Greek: An Updating of a Survey of Recent Work. Cambridge MA and Washington DC. Updating of Nagy 1972, online ed. This edition tracks the page-numberings of Nagy 1972. http://chs.harvard.edu/publications/.

Nagy, G. 2008|2009. Homer the Classic. Online | printed version.

http://chs.harvard.edu/publications/ | Hellenic Studies 36. Cambridge MA and Washington DC.

Nagy, G. 2009|2010. Homer the Preclassic. Online | printed version. http://chs.harvard.edu/publications/ | Berkeley and Los Angeles CA.

Nagy, G. 2009a. "Hesiod and the Ancient Biographical Traditions." The Brill Companion to Hesiod (ed. F. Montanari, A. Rengakos, and Ch. Tsagalis) 271-311. Leiden. Also available online at http://chs.harvard.edu/publications/.

Nagy, G. 2009b. Online and fuller version of Nagy 2005b. http://chs.harvard.edu/publications/.

Pache, C. O. 2009. “The Hero beyond Himself: Heroic Death in Ancient Greek Poetry and Art.” In Albesmeier 2009:88-107

Parry, A. 1971. ed. The Making of Homeric Verse: The Collected Papers of Milman Parry. Oxford.

Radloff, W. 1885. Proben der Volksliteratur der nördlichen türkischen Stämme V: Der Dialekt der KaraKirgisen. St. Petersburg. 
Radloff, W. [1990]. Preface of Radloff 1885. Translated by G. B. Sherman and A. B. Davis. Oral Tradition 5:73-90.

Saussure, F. de. 1916. Cours de linguistique générale. Critical ed. 1972 by T. de Mauro. Paris.

Saussure, F. de. 1966. Course in General Linguistics (tr. W. Baskin). New York.

Sinos, D. S. 1980. Achilles, Patroklos, and the Meaning of Philos. Innsbrucker Beiträge zur Sprachwissenschaft 29. Innsbruck.

Stähler, K. P. 1967. Grab und Psyche des Patroklos: Ein schwartzfiguriges Vasenbild. Münster.

Theiler, W. 1962. "Ilias und Odyssee in der Verflechtung ihres Entstehens." Museum Helveticum 19:1-27.

Watkins, C. 1995. How to Kill a Dragon: Aspects of Indo-European Poetics. New York and Oxford.

West, M. L. 2007. Indo-European Poetry and Myth. Oxford. 